\title{
ESG Versus Corporate Financial Performance: Evidence from East Asian Firms in the Industrials Sector
}

\author{
RIM EL KHOURY ${ }^{1}$, VIVIANE NAIMY ${ }^{2}$, SAHAR ISKANDAR ${ }^{3}$ \\ Department of Accounting and Finance, Notre Dame University, Louaize, Lebanon. \\ ${ }^{1} \mathrm{E}$-mail: rkhoury@ndu.edu.lb \\ 2E-mail:vnaimy@gmail.com \\ ${ }^{3}$ E-mail: sahar.iskandar@yahoo.com
}

\begin{abstract}
Given the unsettled ESG-CFP (Environmental, Social, Governance-Corporate Financial Performance) relationship and the scarcity of research covering emerging markets firms and the impact of each of the ESG pillars on CFP while considering the industry sector categories, this paper is pioneer in investigating this relationship for 108 East Asian listed firms operating in the Industrials sector for the period extending from 2011 to 2017. The overall ESG scores together with their components are used to study their impact on CFP while considering accounting (Return on Assets (ROA) and Return on Equity (ROE)), and market measures (Stock Return (RET) and Price-toBook ratio (PB)). We used panel corrected standard errors to address contemporaneous cross-correlations related to the panel cross-sections. Our findings showed that the ESG-CFP relationship depends on the ESG pillars, the type of CFP measures, and the industry nature. No relationship was detected between ESG and CFP when proxied by accounting measures while a concave relationship with RET and a convex relationship with PB were revealed. When ESG pillars were considered separately, a convex relationship was obtained between Environmental and accounting performances and between Governance and PB while a concave relationship was depicted between Social and accounting performances. At the industry level, ESG negatively impacted the market performance in the Transportation industry compared to no impact in the Capital Goods industry. Consequently, ESG investment decisions in East Asian firms must be well calibrated and planned out to avoid undesired financial outcomes, while a shift in the mindset of managers toward a better ESG development is necessary to attain short-term gains and sustainable fiscal and social advantages.
\end{abstract}

Keywords: ESG, Panel Regression Model, Corporate Financial Performance, CSR, Industrials Sector, Market and Accounting Measures, East Asian Countries

JEL Classification: C33, G3, G23, M2

Recibido: 7 de Enero de 2021

Aceptado: 2 de Febrero de 2021 


\section{Introduction}

Over the past decade and following the global financial crisis, the effect of climate change, and the many corporate scandals that took place around the world, governments, consumers and investors became more demanding and required transparency regarding all matters impacting environmental, economic and social dimensions. Thus, many companies started to publish sustainability reports, also known as corporate social responsibility (CSR) or environmental, social and governance (ESG) reports. Thousands of empirical studies have investigated whether the integration of the ESG concept into firm's core processes rewarded shareholders, yielded higher profits, and/or enhanced its valuation. Results remain ambiguous, inconclusive, and sometimes contradictory. While most of the studies found a positive relationship between CSR, ESG integrations and corporate financial performance (CFP) (Chelawat \& Trivedi, 2016), few others found contradictory results reporting a negative (SoYeon et al., 2016) or even a U-shape relationship (Barnett \& Salomon, 2012; Ferrero-Ferrero et al., 2016; Garcia et al., 2017). On the other hand, the studies conducted by country, region or industry, found a mixed ESGCFP relationship (Auer \& Schuhmacher, 2016; Baird et al., 2012; Barnett \& Salomon, 2012).

Although the ESG-CFP question was amply analyzed, the existing literature did not succeed to cover many of its important aspects. Specifically, not only the inclusion of developing countries firms in the sample was not enough (Naimy \& Bou Zeidan, 2019; Nyeadi et al., 2018), but also the corresponding results were mixed and inconclusive (Güler et al., 2010; Zhao et al., 2018). Also, the corporate governance dimension was often disregarded (Galbreath, 2013) and only the overall ESG score's effect on the CFP of firms was addressed while ignoring the pillar levels. Another important deficit is observed when the generalization of results is done based on several industries taken all together at once (Soana, 2011) despite the fact that ESG characteristics can significantly vary across industries.

To this end, the purpose of this paper is to extend the scope of earlier studies by elucidating such relationship and fill the existing literature gap by identifying how ESG aspects can impact CFP while measuring and analyzing separately the impact of the ESG components - environmental, social and governance - on the CFP of eight emerging countries' businesses in East Asia and providing empirical evidence for 108 listed firms operating in the Industrials sector for the period 2011-2017 while integrating accounting and market-based financial variables.

The paper proceeds as follows. Section 2 presents the literature review. Section 3 explains the methodology and describes the data. Section 4 presents the findings while Section 5 concludes and discusses the results' implications.

\section{Literature Review}

Since the mid of the twentieth century, more than 2,000 empirical studies were conducted to test the relationship between CSR and CFP and this number has been at an increasing trend (Friede et al., 2015). Orlitzky et al., (2003) presented a meta-analysis of 52 studies testing the relationship between corporate social performance (CSP) and CFP. The results confirm the positive relationship with the strongest one for the social dimension. According to the authors, this relationship is strongly confirmed by using accounting rather than market-based measures. Horváthová (2010) conducted a metaanalysis covering 37 studies examining the relationship between environmental CSR and CFP where half of them found a positive relationship and the other half found either a negative or an insignificant impact. Positive effect of CSR on CFP was found in the United States, the United Kingdom (Salama, 2005), Canada (Mahoney \& Roberts, 2007), Greece (Karagiorgos, 2010), and in several other European countries (Moneva \& Ortas, 2010). In fact, the correlation was overall positive, however when ESG was dissected according to its three pillars, it was revealed that CFP was not equally affected by each pillar separately. Governance scores exhibited a significant positive effect on CFP while both environmental and social scores showed a minor association with CFP.

Fauzi \& Idris (2009) found a positive relationship in manufacturing companies listed in Jakarta Stock Exchange (Indonesia) for the year 2007 supporting both slack resource theory and good management theory. In Malaysia, Ahamed et al. (2014) supported the positive relationship between accounting 
measures (return on assets (ROA) and return on equity (ROE)), and CSP. CSP was measured by the content analysis of annual reports based on environment, community, marketplace, and workplace dimension. Achim et al. (2016) investigated the relationship between corporate governance and CFP of 76 companies listed on the Bucharest Stock Exchange (Romania) between 2001 and 2011. CFP was measured by market capitalization, price-to-book ratio (PB), Tobin's $Q, R O A$, and ROE. They found a positive and significant relationship for all CFP measures except for ROE. Chelawat \& Trivedi (2016) used a panel data regression on listed companies in India and found that companies with good ESG have a better CFP. Variables used to proxy CFP were return on capital employed (ROCE) and Tobin's Q while control variables were debt-to-equity ratio as a proxy for risk and the logarithm of total asset as a proxy for size. Miralles-Quirós et al. (2018) focused on the firms listed on São Paulo Stock Exchange (Brazil) for the period 2010-2015. The regression models included leverage (debt to equity ratio) and firm size as control variables. They stated that Brazilian investors favoured CSR activities as a valueenhancing tool. Zhao et al. (2018) used a panel regression model to explore the nature of the relation between ESG application and financial outcomes in the largest listed Chinese power generation groups over 10 years. Leverage and size were chosen as control variables. Although the authors faced a setback since the ESG disclosure reports in China were not clear nor deep and their scope was not vast, the quantitative approach proved that the relationship was positive.

A negative relationship between CSR and CFP was detected by Bird et al. (2007), Fisher-Vanden \& Thorburn (2011), and SoYeon et al. (2016). Similarly, Güler et al. (2010) conducted their study on listed companies on Istanbul Stock Exchange (ISE) and measured CFP using accounting ratios (ROA, ROE and return on sales (ROS)) while including three control variables, mainly size, risk, and R\&D. Content analysis of annual reports was also implemented to assess CSR. They found no association between CSR and CFP. Han et al. (2016) examined the CSR-CFP relationship on firms listed in the Korea Composite Stock Price Index (KOSPI) for the period 2008-2014 and identified a negative U-curve relationship between the environmental pillar and CFP, a positive inverse U-curve between governance pillar and CFP and no link between the social pillar and CFP. Garcia et al. (2017) studied the relationship between ESG and CFP for 365 listed companies in sensitive industries operating in the BRICS nations between 2010 and 2012. By using a panel data analysis, they found an inverted U-curve relationship between ESG and systematic risk, suggesting the presence of an optimal level of ESG. Barnett \& Salomon (2012) studied a panel of data constituted of 3,100 firms from 1991 to 2006 using ROA as a measure of CFP. After controlling for firm size, debt ratio, R\&D ratio and advertising intensity, the results showed that high CSR led to high CFP up to a certain point where CSR costs start to outweigh financial benefits.

Ferrero-Ferrero et al. (2016) explored the effect of ESG on CFP for firms listed in the EU-15 countries from 2002 to 2011 by applying the Generalized Method of Moments (GMM). They used the economic performance score to measure CFP and ESG pillars dimensions while controlling for size, capital expenditure, sales growth rate and debt level. They concluded that ESG activities increased economic performance until a well-defined ESG threshold supporting the presence of a nonlinear relationship between ESG and CFP.

Baird et al. (2012) confirmed that the CSR-CFP relationship differs from industry to industry and even by dimension within each industry. Surprisingly, Auer \& Schuhmacher (2016) found that the relationship between stock return (RET) and ESG performance depends on the region in which the firm operates. While this relationship is positive in Asia-Pacific region and in the United States, it is less evident in Europe.

Actually, the positive relationship between CSR and CFP is ambiguous, and the payoff from investing in CSR is not guaranteed. While a positive relationship indicates that the investment is likely to pay off, a negative relationship suggests that CSR is a waste of money. The opposing results may be due to several factors, such as the definition of the CSR concept (Ruf et al., 2001), the omission of some control variables (McWilliams \& Siegel, 2000), the poor measurement of CFP (Davidson \& Worrell, 1990), and the sampling techniques (van Beurden \& Gössling, 2008). Another justification for such results is related to the fact that potential benefits of implementing ESG activities may not be 
cultivated immediately and it may take time to materialize with a negative short-term effect and positive long-term effect.

The objective of this paper is therefore to investigate the relationship nature between ESG and CFP for the selected sample of firms using accounting, market, and mixed-based measures of CFP while testing the contribution of each of the ESG pillars to the ESG- CFP link.

\section{Methodology and Data}

The sample is limited to 108 East Asian companies operating in the Industrials sector and pertaining to three industry groups namely, Capital Goods, Commercial and Professional Services, and Transportation, and are listed on the Thomson Reuters Global Emerging Markets and the DFA Emerging Markets Core Equity Portfolio for the period spanning from 2011 to 2017. The corresponding number of observations is 7,326 and are retrieved from Reuters Database. The list of the selected companies and countries is shown in Appendix $A$.

We opted to exclude US and European firms from the sample given the significant differences with regard to the institutional context and company profiles in advanced economies. While advanced economies are characterized by reliable enforcement of liability laws and efficient dissemination of information, emerging countries have limited enforcement of liabilities and little dissemination of information. Also, their capital markets are characterized by vigilant monitoring and disclosure rules which is not the case in emerging countries.

\subsection{Selection of variables}

\subsubsection{Dependent variables}

The dependent variable is CFP and is measured using accounting and market-based measures (McGuire et al., 1988; Nelling \& Webb, 2009; Velte, 2017). While accounting measures are sensitive to company specific risk, market measures are sensitive to systematic risk (McGuire et al., 1988). We opted to use both types of CFP measures in order to produce a coherent picture of the hypothesized relationships with ESG. ROA and ROE are selected as the accounting measures, RET as the market measure, and PB as the mixed measure.

\subsubsection{Independent variables}

CSR and corporate governance are not to be treated separately when studying CFP (Galbreath, 2013; Saltaji, 2013). Consequently, one variable that can represent both CSR and corporate governance at once is ESG. To evaluate the impact of ESG on CFP, we use the one-year lagged variables of ESG (ESG $\mathrm{t}-1$ ), (Graves \& Waddock, 1994; McWilliams \& Siegel, 2001). On the other hand, and in order to test which of the three components of ESG better contributes to CFP, we use each component distinctly: Environmental score $\left(\mathrm{ENV}_{\mathrm{t}-1}\right)$, Social score $\left(\mathrm{SOC}_{\mathrm{t}-1}\right)$, and Governance score $\left(\mathrm{GOV}_{\mathrm{t}-1}\right)$. We also use the

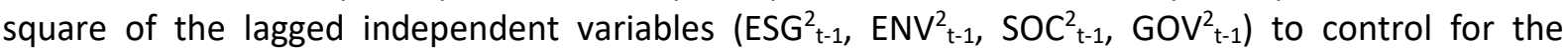
presence of a U-curve relationship between ESG and CFP and verify potential nonlinearity (Brammer et al., 2006; Han et al., 2016; Nollet et al., 2016).

\subsubsection{Control variables}

We use the control variables to include company specific characteristics as potential determinants of CFP when studying ESG-CFP link (Velte, 2017 and Waddock \& Graves, 1997). These variables are Firm Size (SIZE) (+), Unsystematic Risk (LEV) (-), Industry (IND), the lagged dependent variables $\left(\mathrm{ROA}_{\mathrm{t}}\right.$ 1, $\mathrm{ROE}_{\mathrm{t}-1}, \mathrm{RET}_{\mathrm{t}-1}, \mathrm{~PB}_{\mathrm{t} 1}$ ), and R\&D. In fact, large firms might have a better profitability due to economies of scale and scope and might be related to the extent of stakeholders' expectations and concerns regarding socially responsible activities (Hillman \& Keim, 2001). The unsystematic risk also known as specific firm risk is measured by the leverage ratio and therefore, firms with high levels of ESG incur lower costs of debt thus increase their CFP (Orlitzky \& Benjamin, 2001). Similarly to SIZE, IND is 
identified as an important control variable (Griffin \& Mahon, 1997) since different industries operate in different contexts and face different social and environmental concerns and stakeholders' reaction to firms' ESG is related to the industry by itself. To this end and since there are three industry groups within the Industrials sector that we selected, we created three dummy variables to eliminate the effects of Industry. To address the endogeneity problem and capture the potential impact that past CFP might affect current CFP, we included all the lagged dependent variable in the regressions (Han et al., 2016). Finally, we considered R\&D expenses, also known as innovation, since they can have an impact on the ESG- CFP relationship (McWilliams \& Siegel, 2000).

All the dependent, independent and control variables together with their definitions, acronyms, and expected impact (sign) on ESG are depicted in Table 1.

Table 1. Summary of the variables with their expected sign

\begin{tabular}{|c|c|c|c|}
\hline & Symbol & Definition & $\begin{array}{l}\text { Expected } \\
\text { Sign }\end{array}$ \\
\hline \multirow{4}{*}{ 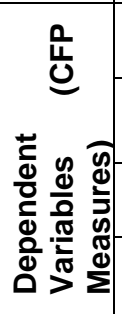 } & $\mathrm{ROA}_{i t}$ & $\begin{array}{l}\text { Return on Assets at time t of company } \mathrm{i} \text { is defined as Net Income divided } \\
\text { by Average Total Assets }\end{array}$ & \\
\hline & $\mathrm{ROE}_{\mathrm{it}}$ & $\begin{array}{l}\text { Return on Equity at time } t \text { of company } i \text { is defined as Net Income divided } \\
\text { by Average Common Equity }\end{array}$ & \\
\hline & RET it & $\begin{array}{l}\text { Stock Return at time t of company } i \text { is defined as the Yearly Price change } \\
\text { plus Dividends }\end{array}$ & \\
\hline & $P B_{i t}$ & $\begin{array}{l}\text { Price-to-Book Value per share at time } t \text { of company i is defined as Current } \\
\text { Market Price divided by Current Book Value per share }\end{array}$ & \\
\hline \multirow{8}{*}{ 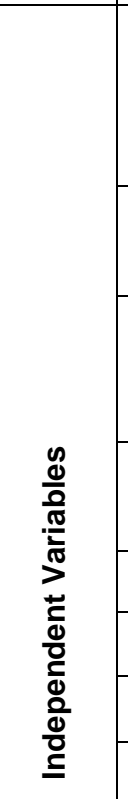 } & $E S G_{i t-1}$ & $\begin{array}{l}\text { Overall ESG score at time t- } 1 \text { of company i. } \\
\text { It ranges from } 0-100 \text { where a higher value indicates a higher ESG score. } \\
\text { This score is based on } 178 \text { company level metrics which are grouped into } \\
10 \text { categories before rolling them up into the three pillars of ESG (Refinitiv, } \\
2020 \text { ). }\end{array}$ & Negative \\
\hline & $E N V_{i t-1}$ & $\begin{array}{l}\text { Environmental score at time t-1 of company i } \\
\text { This pillar is derived from a predetermined weighted score on indicators } \\
\text { related to: (i) emission, (ii) innovation, and (iii) resource use }\end{array}$ & Negative \\
\hline & $\operatorname{SOC}_{i t-1}$ & $\begin{array}{l}\text { Social score at time t-1 of company l } \\
\text { This pillar is derived from a predetermined weighted score on indicators } \\
\text { related to: (i) workforce, (ii) human rights, (iii) community, (iiii) product } \\
\text { responsibility. }\end{array}$ & Negative \\
\hline & GOV $_{\mathrm{it}-1}$ & $\begin{array}{l}\text { Corporate Governance score at time t-1 of company } \mathrm{i} \\
\text { This pillar is derived from a predetermined weighted score on indicators } \\
\text { related to: (i) management (ii) shareholders (iii) CSR strategy. }\end{array}$ & Negative \\
\hline & $E G^{2} i t-1$ & Overall ESG score square at time $\mathrm{t}-1$ of company $\mathrm{i}$ & Positive \\
\hline & $\mathrm{ENV}^{2} \mathrm{it}-1$ & Environmental score square at time $\mathrm{t}-1$ of company $\mathrm{i}$ & Positive \\
\hline & $\operatorname{SOC}^{2} i t-1$ & Social score square at time $\mathrm{t}-1$ of company $\mathrm{i}$ & Positive \\
\hline & $\mathrm{GOV}^{2} \mathrm{it}-1$ & Corporate Governance score square at time t- 1 of company i & Positive \\
\hline \multirow{7}{*}{ 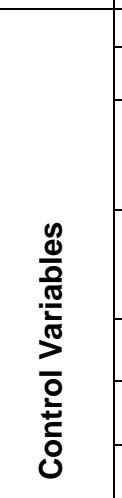 } & SIZE $_{i t-1}$ & Logarithm of Total Assets at time t- 1 of company $\mathrm{i}$ & Positive \\
\hline & LEV $_{\mathrm{it}-1}$ & Total Debt divided by Total Assets at time t- 1 of company i & Negative \\
\hline & $\mathrm{ROA}_{\mathrm{it}-1}$ & $\begin{array}{l}\text { Return on Assets at time } \mathrm{t}-1 \text { of company i defined as Net Income divided } \\
\text { by Average Total Assets }\end{array}$ & Positive \\
\hline & $\mathrm{ROE}_{\mathrm{it}-1}$ & $\begin{array}{l}\text { Return on Equity at time } \mathrm{t}-1 \text { of company i defined as Net Income divided } \\
\text { by Average Common Equity }\end{array}$ & Positive \\
\hline & RET $_{i t-1}$ & Stock Return at time t-1 of company i & Positive \\
\hline & $P B$ it-1 & Price-to-Book Value per Share at time t-1 of company i & Positive \\
\hline & IND & Dummies for each industry group & \\
\hline
\end{tabular}

\subsection{Regressions}


The panel data is employed to study the ESG-CFP relationship using the fixed-effect estimation technique (Hausman Test). In each equation, CFP is represented either by using accounting or marketbased measures (ROA and ROE), (RET) or both (PB). We apply a two-model approach. In the first one, we control for SIZE, LEV, and IND with one year lagged dependent variable and in Model 2, we add one year lagged squared independent variable to test for non-linearity. Also, our modelling process involves two phases. The first one corresponds to when the overall ESG score is considered (Models 1 \& 2), and the second one when each of the three pillars of ESG are considered (Models 3 \& 4).

Model 1:

$$
\operatorname{CFP}_{i, t}=\beta_{0}+\beta_{1} E S G_{i, t-1}+\beta_{2} \operatorname{SIZE}_{i, t-1}+\beta_{3} L E V_{i, t-1}+\beta_{4} C F P_{i, t-1}+\beta_{5} I N D_{i, t}+\varepsilon_{i, t}
$$

Model 2:

$$
C F P_{i, t}=\beta_{0}+\beta_{1} E S G_{i, t-1}+\beta_{2} E S G_{i, t-1}^{2}+\beta_{3} S I Z E_{i, t-1}+\beta_{4} L E V_{i, t-1}+\beta_{5} C_{F P} P_{i, t-1}+\beta_{6} I N D_{i, t}+\varepsilon_{i, t}
$$

Where CFP $_{i, t}$ represents the dependent variable measured for company $i$, in period $t$, through the use of: (1) ROA, (2) ROE, (3) RET and (4) PB respectively. $\varepsilon_{i, t}$ is the error term or residual which represents part of the observed CFP that is not explained by the model.

Model 3:

$$
\begin{aligned}
C F P_{i, t}=\beta_{0}+ & \beta_{1} E N V_{i, t-1}+\beta_{2} S O C_{i, t-1}+\beta_{3} G O V_{i, t-1}+\beta_{4} S I Z E_{i, t-1}+\beta_{5} L E V_{i, t-1}+\beta_{6} C F P_{i, t-1} \\
& +\beta_{7} I N D_{i, t}+\varepsilon_{i, t}
\end{aligned}
$$

Model 4:

$$
\begin{aligned}
& \quad \operatorname{CFP}_{i, t}=\beta_{0}+\beta_{1} E N V_{i, t-1}+\beta_{2} \text { SOC }_{i, t-1}+\beta_{3} G_{O O V_{i, t-1}} \\
& +\beta_{4} E N V_{i, t-1}^{2}+\beta_{5} \text { SOC }_{i, t-1}^{2}+\beta_{6} \text { GOV V }_{i, t-1}^{2}+\beta_{7} \operatorname{SIZE}_{i, t-1}+\beta_{8} L E V_{i, t-1} \\
& +\beta_{9} C F P_{i, t-1}+\beta_{10} I N D_{i, t}+\varepsilon_{i, t}
\end{aligned}
$$

In addition to the above, we extended the model to test for each industry separately: on the one hand, the overall impact of ESG score on CFP (Models 1\&2), and the impact of each of the ESG pillars on CFP (Models $3 \& 4$ ) on the other hand. We used Stata software to perform our models.

\subsection{Data}

A summary of the descriptive statistics related to the independent variables and the dependent and control variables is portrayed in Appendix B and Appendix C respectively. No sign of multicollinearity was detected between the variables as reflected in Appendix $D$ (Pearson Correlation Matrix) however, the highest correlation coefficients (above 0.7) are revealed between ESG and its two pillars (ENV and SOC), which indicates that they will not be included together in one regression. Also, all variables are stationary since based on the Augmented Dicky Fuller (ADF) test, the p-values are below 0.05 , thus rejecting the null hypothesis. Serial correlation was detected as confirmed by Wooldridge test implemented to each of the regression equations (Appendix E), however, serial correlation is considered a problem only for large time dimensions' panel data spanning for periods between 20 to 30 years (Brooks, 2008), which is not the case of this study, although it will be dealt with in the regression models. All the regression equations are estimated using the fixed effect estimator (FE) approach ( $p$-value is zero) as confirmed by Hausman Test (Appendix F). Heteroscedasticity was also detected by Wald test (all $p$-values $=0$ ). To correct for the presence of heteroscedasticity, we checked the variables' cross-sectional dependency using Pesaran test since the time-series datasets are in the form of small T and large $N$ (Appendix $G$ ). It was confirmed that crosssectional dependency exists within all models, except in Models 3 and 4 when RET is used as the dependent variable. Accordingly, Driscoll-Kray standard errors is applied to correct for heteroscedasticity (Hoechle, 2007), while the fixed effect with robust and clustered standard errors known as Huber/White estimators - is used for Models 3 and 4. 


\section{Findings}

FE model is estimated for four independent variables, namely ROA, ROE, RET, and PB (Appendix H -Tables 1, 2, 3, and 4). A summary of the relationship structure by dependent variables is done in Table 2.

Table 2. Summary of relationships by dependent variable by pillar

\begin{tabular}{|l|c|c|c|c|c|}
\hline Relationship Tested & $\begin{array}{c}\text { Mean } \\
\text { of Pillar }\end{array}$ & ROA & ROE & RET & PB \\
\hline ESG $\rightarrow$ CFP & 41.54 & No & No & Concave (50.25) & Convex (59.63) \\
\hline ENV $\rightarrow$ CFP & 45.42 & Convex (45.71) & Convex (46.89) & No & No \\
\hline SOC $\rightarrow$ CFP & 41.31 & Concave (39.37) & Concave (41.18) & Positive & No \\
\hline GOV $\rightarrow$ CFP & 47.78 & Negative & No & Positive & Convex (55.35) \\
\hline
\end{tabular}

Note: Numbers in parentheses represent the turning points for a non-linear relationship and are equal to (-) coefficient of the linear term) $/ 2^{*}$ coefficient of the squared term.

\subsection{The impact of overall ESG on CFP}

Results revealed no relationship between ESG and CFP when proxied by accounting measures ROA (Appendix $\mathrm{H}$ - Table 1) and ROE (Appendix $\mathrm{H}$ - Table 2), a concave relationship between ESG and RET (Appendix $\mathrm{H}$ - Table 3) and a convex relationship between ESG and PB (Appendix H- Table 4). The inversely U-shape (concave) of RET with ESG contradicts our expectation. Thus, investment in ESG is perceived as a value creating by the financial markets at a lower level of investment, but it becomes a destroying activity as the level of ESG investment increases at the second stage, implying that the costs of being socially responsible are greater than the benefits the company can get. The results in the short run are consistent with the value enhancing and stakeholder theories, while the negative results obtained in the long run are confirming the trade-off theory. The stopping point is 50.25 , which is above the average of 41.54, suggesting that improving ESG in this sector is still helpful in improving RET. The convex U-shape relationship between ESG and PB suggests that ESG investment must increase beyond a certain level to have a positive impact on this ratio, thus the potential benefits of implementing ESG activities may not be cultivated immediately. The threshold level of ESG score is 59.63 , which is far greater than the current average of 41.54 in this sector, which means that firms are not currently benefiting from ESG investment. An alternative supporting argument is that ESG investment is likely to be associated with capital investment (sunk costs) resulting in economy of scale. Given this argument, higher investment in ESG is needed to generate higher financial returns for the firm as mentioned by McWilliams \& Siegel (2001). The control variable SIZE is found to have a negative impact on CFP in all regressions, while LEV is not significant in all regressions and models.

\subsection{The impact of ENV on CFP}

ENV only affects accounting performance with a convex relationship, illustrating the presence of a U-shape relationship. More specifically, while a negative relation between ENV and accounting performance may occur at an early stage of ENV, there is a turning point after which the relationship becomes positive. Our results complement those of Fisher-Vanden \& Thorburn (2011) who found a negative relationship and those of Nollet et al.(2016) who found a U-Shape relationship. The threshold level is between 45.71 and 46.89, which is slightly higher than the current ENV score of 45.42 . This recommends that improving environmental responsibility is a procedure that takes a long time to reap its benefits. Thus, companies operating in Industrials sector need to continue improving their ENV efforts. In fact, while the market understands the need to spend resources on complying with environmental regulations, it does not reward for expenses that go beyond this objective. Firms should be rational enough to know how much resources they need to devote to ENV to improve their performances and enhance stakeholders' expectations. In the short run, our results partially revealed a negative influence from environmental proactivity on CFP which corroborates the findings of 
González-Benito \& González-Benito (2005). Our results support both the shareholder expense theory and the trade-off theory. In the long run, the relationships are supportive of the stakeholder theory and the value enhancing theory which is consistent with the findings of Dobre et al. (2015) and Miroshnychenko et al. (2017).

\subsection{The impact of SOC on CFP}

The SOC pillar displayed a concave relationship for accounting measures and a positive relationship for market measure. This suggests that a better SOC is associated with a better short run CFP, while an augmented SOC is associated with a lower CFP in the long run. Our results support the law of diminishing marginal returns known in economics. As the input has a positive effect on the output, its effect starts to decrease as the input increases. Similarly, when SOC increases, its marginal contribution to the accounting performance starts to decrease between the scores of 39.37 for ROA and 41.18 for ROE, thus when the level of SOC investment exceeds the threshold (its average is currently 41.31), it is perceived as a negative news and we may conclude that improving SOC investments is not helpful to improve accounting performance for emerging firms operating in the Industrials sector. In other words, when companies are using their resources for non-profit social activities, they will have less resources in the long run that could have been used to invest in positive net present value projects, which will put the firm at a disadvantage (Balabanis et al., 1998) supporting the tradeoff theory. Consequently, in the long run, the costs will outweigh the benefits, explaining the inverse relationship with CFP. Also, our results showed the insignificant impact of SOC on PB. This could be attributed to the fact that, in emerging countries, social activities are not as attractive to consumers as goods' prices, a conclusion consistent with the findings of Nyeadi et al. (2018).

\subsection{The impact of GOV on CFP}

Our results show that GOV has no impact on accounting measures, while it has a positive effect on RET and a U-shaped relationship with $\mathrm{PB}$, which means that only an augmented corporate governance compliance is associated with positive long-term financial results. Since the threshold level for PB is 55.35 , while the average GOV is 47.78 , this suggests that improving GOV will ultimately pay off RET but might need time to enhance PB. The U-shaped supports the work of Xie et al. (2019) who found that the GOV score has a negative impact on corporate efficiency of 6,631 companies from 74 countries at a lower governance level while it has a stronger positive relationship at the upper level. The quadratic relationship with CFP is also consistent with Nollet et al. (2016) findings.

\subsection{The impact of innovation}

Because many firms in our sample did not report R\&D expenditures, and to avoid running the regression on a different sample, we followed previous literature (Barnett \& Salomon, 2012) in assuming that unreported expenditures were immaterial. Therefore, we assign zero values to those firms whose R\&D observations were missing, and we controlled the presence of R\&D by a dummy variable. This dummy variable takes the value of 1 if $R \& D$ expenses are missing, zero otherwise. Table 3 compares ESG-CFP link before and after controlling for R\&D and the last two columns report the impact of R\&D dummy and R\&D ratio (defined as the R\&D expenses to total sales) on CFP. The objective is to assess whether adding R\&D into the model will affect the ESG-CFP relationship.

Table 3 shows that while the impact of R\&D ratio on CFP depends on CFP measures, controlling for R\&D did not change most of the relationships previously identified. The impact of SOC on accounting performance lost its significance when R\&D was controlled for, while ENV-CFP link changes from being insignificant to a non-linear convex relationship when CFP is measured by PB. Our results partially support those of Hull \& Rothenberg (2008) who found that the CSR-CFP relationship is significant even if the organizational innovation rate and the extent of product differentiation are considered, and those of Andrade Rocha et al. (2019) who suggested that the more efficient firms achieve more profits from R\&D investment, and contradict those of McWilliams and Siegel (2001) who concluded that when 
R\&D intensity appears, CSR lost its impact on profitability. On the other hand, the negative relationship between $R \& D$ and accounting performance indicates that when a firm spends resources on $R \& D$ activities, its short-term performance is negatively affected.

Table 3. ESG-CFP link before and after controlling R\&D by dependent variable

\begin{tabular}{|c|c|c|c|c|c|}
\hline Sector & CFP & $\begin{array}{l}\text { Model and } \\
\text { Relationship } \\
\text { (before R\&D) }\end{array}$ & $\begin{array}{l}\text { Impact of ESG after } \\
\text { introducing RD }\end{array}$ & $\begin{array}{l}\text { Impact of RD } \\
\text { (Dummy) }\end{array}$ & $\begin{array}{l}\text { Impact of amount of } \\
\text { RD (RD ratio=RD } \\
\text { Expenses/Total Sales) }\end{array}$ \\
\hline \multirow{4}{*}{ ESG } & ROA & $\begin{array}{l}\text { Models } 1 \text { and } 2 \text { Not } \\
\text { significant }\end{array}$ & SAME & Not significant & Negative* $^{*}$ \\
\hline & ROE & $\begin{array}{l}\text { Models } 1 \text { and } 2 \\
\text { Not significant }\end{array}$ & SAME & Not significant & Negative $e^{\star * *}$ \\
\hline & RET & Model 2- Concave & SAME & Not significant & Not significant \\
\hline & PB & Model 2- Convex & Linear, Negative & Not significant & Not significant \\
\hline \multirow{4}{*}{ ENV } & ROA & Model 2-Convex & SAME & Not Significant & Negative** \\
\hline & ROE & Model 2-Convex & SAME & Not Significant & Negative*** \\
\hline & RET & $\begin{array}{l}\text { Model } 1 \text { and 2-Not } \\
\text { significant }\end{array}$ & SAME & Not significant & Not significant \\
\hline & PB & $\begin{array}{l}\text { Model } 1 \text { and 2-Not } \\
\text { significant }\end{array}$ & Convex & Not significant & Not significant \\
\hline \multirow{4}{*}{ SOC } & ROA & Model 2-Concave & Not significant & Not Significant & Negative** \\
\hline & ROE & Model 2-Concave & Not significant & Not Significant & Negative ${ }^{\star \star *}$ \\
\hline & RET & Model 1-Positive & SAME & Not significant & Not significant \\
\hline & PB & $\begin{array}{l}\text { Model } 1 \text { and 2-Not } \\
\text { significant }\end{array}$ & SAME & Not significant & Not significant \\
\hline \multirow{4}{*}{ GOV } & ROA & Model 1-Negative & SAME & Not Significant & Negative* $^{*}$ \\
\hline & ROE & $\begin{array}{l}\text { Model 1- } \\
\text { Not significant }\end{array}$ & Negative* & Not Significant & Negative $e^{\star * *}$ \\
\hline & RET & Model 2-Positive & SAME & Not significant & Not significant \\
\hline & PB & Model 2-Convex & SAME & Not significant & Not significant \\
\hline
\end{tabular}

\subsection{The impact of industry}

Given that Commercial and Professional Services industry has a small number of observation $(\mathrm{N}=12$, with only 3 companies), we dropped this industry out from the sample. Table 4 summarizes the findings by industry and Appendix I (Tables 1 through 8 ) reports all the regression results for Capital Goods and Transportation industries. Our results show that the ESG-CFP link is not the same for both industries which is consistent with Baird et al. (2012) findings. While ESG has no impact on ROA and RET in the Capital Goods industry, it has a concave relationship with ROA and a negative relationship with RET in the Transportation industry.

Although both industries belong to the same sector, the impact of each pillar within each industry on CFP is not the same. While there is a convex relationship between ENV and ROA in both industries, the threshold level varies intensely. The low threshold level for Capital Goods industry indicates that improving environmental responsibility pays off faster compared to Transportation industry. On the other hand, SOC-CFP link is the same for both industries, except for PB where the threshold obtained varies significantly. While a small increase in SOC beyond 23.41 may lead to a detrimental effect on accounting performance in the Capital Goods industry, SOC should increase beyond 69.67 in the Transportation Industry. Given that the current SOC averages are 39.06 and 47.17 for Capital Goods and Transportation industries respectively (Table 4), firms operating in the former are negatively 
affected by SOC and positively affected in the latter. Therefore, while reducing SOC efforts is needed in Capital Goods industry, refining efforts may be helpful to improve ROA and ROE in the Transportation industry. Finally, we found that GOV has a concave relationship in the Transportation industry, indicating that a high governance compliance does not translate into a better CFP and that a small, yet effectively independent board, is a step toward long term positive financial results. Finally, our results show that GOV does not have any significant impact on accounting performance in the Capital Goods industry.

Table 4. Comparison of results by sector

\begin{tabular}{|c|c|c|c|c|c|c|c|}
\hline \multirow[t]{2}{*}{ Pillar } & \multirow[t]{2}{*}{ CFP } & \multicolumn{2}{|c|}{ Industrials Sector } & \multicolumn{2}{|c|}{ Capital Goods Industry } & \multicolumn{2}{|l|}{ Transportation Industry } \\
\hline & & Relation & Mean & Relation & Mean & Relation & Mean \\
\hline \multirow{4}{*}{ ESG } & ROA & No Relation & \multirow{4}{*}{41.54} & No Relation & \multirow{4}{*}{40.31} & Concave $^{* * *}(41.31)$ & \multirow{4}{*}{44.64} \\
\hline & ROE & No Relation & & No Relation & & No Relation & \\
\hline & RET & Concave (50.25) & & No Relation & & Negative* $^{*}$ & \\
\hline & PB & Convex (59.63) & & Convex*** $(52.82)$ & & Negative $e^{\star \star *}$ & \\
\hline \multirow{4}{*}{ ENV } & ROA & Convex (45.71) & \multirow{4}{*}{45.42} & Convex $^{* \star *}(42.39)$ & \multirow{4}{*}{44.74} & Convex** $^{*}(67.81)$ & \multirow{4}{*}{46.42} \\
\hline & ROE & Convex (46.89) & & Convex $^{* * *}(72.50)$ & & Negative $^{*}$ for low level & \\
\hline & RET & No Relation & & $\begin{array}{l}\text { Positive* at low } \\
\text { level }\end{array}$ & & Convex $^{* *}(53.46)$ & \\
\hline & PB & No Relation & & No Relation & & No Relation & \\
\hline \multirow{4}{*}{ soc } & ROA & Concave (39.37) & \multirow{4}{*}{41.31} & Concave $^{\star *}(23.41)$ & \multirow{4}{*}{39.06} & Concave $^{* * *}(69.67)$ & \multirow{4}{*}{47.17} \\
\hline & ROE & Concave (41.18) & & 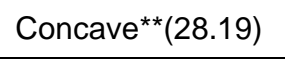 & & Concave $^{\star * *}(76.69)$ & \\
\hline & RET & Positive & & Positive ${ }^{\star \star \star}$ & & Positive** & \\
\hline & PB & No Relation & & Positive* & & No Relation & \\
\hline \multirow{4}{*}{ GOV } & ROA & Negative & \multirow{4}{*}{47.78} & No Relation & \multirow{4}{*}{48.13} & Concave***$(35.87)$ & \multirow{4}{*}{48.40} \\
\hline & ROE & No Relation & & No Relation & & Concave $^{* * *}(48.51)$ & \\
\hline & RET & Positive & & Convex*** (55.68) & & Negative* at low level $^{*}$ & \\
\hline & PB & Convex (55.35) & & Convex $^{\star \star *}(51.66)$ & & No Relation & \\
\hline
\end{tabular}

\section{Discussions and Conclusion}

The impact of ESG on CFP is still changeable. Undoubtedly, this paper succeeded to contribute to the existing literature in determining the ESG-CFP relationship for East Asian companies operating in the Industrials sector. It was shown that ENV, SOC, and GOV have different effect on CFP measures for the overall Industrials sector. Similarly, we found that ESG has a convex relationship in one industry and a concave one in the other. Also, its impact on CFP varied with CFP measures with, always, a nonlinear relationship (either concave or convex).

Therefore, ESG implementation in East Asian firms must be carefully planned out and implemented. In other words, investment allocation decisions in ESG pillars must be well calibrated to the financial status of each firm and vigorously controlled to avoid undesirable fallouts. On the other hand, a shift in the mindset of managers toward a better ESG development is necessary not only to attain immediate or short-term gains but also for a long-term sustainable fiscal advantage. The costs of social activities, in the long run, are greater than the benefits the company can obtain in terms of accounting numbers. The inverse $U$-shape relationship (concave) suggests that the level of investment in SOC must be well thought of. Although being socially responsible pays off, firms must always rationalize the level of SOC they are investing in, in order to be able to detect when such resources are no longer enhancing shareholders' wealth. Also, and based on the U-shape relationships that we found, the level of GOV 
implementation seems imperative. Although strategizing and implementing a corporate governance plan might not enhance returns immediately, East Asian firms should continue to morally adopt corporate governance for a sustainable development and long- term financial position enhancement.

Our mixed results regarding ESG-CFP relationship may be attributed to the behaviour of the emerging markets' consumers who are price oriented rather than sustainability oriented, to the managers' know-how who tend to resist changes related to new managing ESG investment techniques and who are invoked by the trade-off and negative synergy theories, and to the nature of ESG disclosures that are voluntary rather than mandatory in emerging countries, which may consequently lead to ambiguous non-financial data reporting.

Although our results are statistically sound, future investigations are recommended where not only ESG scores would be considered but also actual CSR actions that firms have engaged in with a larger sample, a diversified portfolio of industries split into sub-industries while including more control variables such as systematic risk or degree of competition. Another suggested research path may encompass the implementation of non-parametric panel data models to account for non-linearity.

\section{References}

1. Achim, M.-V., Borlea, S.-N., \& Mare, C. (2016). Corporate governance and business performance: Evidence for the Romanian economy. Journal of Business Economics and Management, 17(3), 458474. https://doi.org/10.3846/16111699.2013.834841

2. Ahamed, W. S. W., Almsafir, M. K., \& Al-Smadi, A. W. (2014). Does corporate social responsibility lead to improve in firm financial performance? : Evidence from Malaysia. International Journal of Economics and Finance, 6(3), 126-138. https://doi.org/10.5539/ijef.v6n3p12

3. Andrade Rocha, L., Querido Cardenas, L., Tortato, U., Santos Póvoa, A. C., \& Araújo Silva, N. G. (2019). Innovation and performance: The contribution of investments in R\&D to firm profitability according to the technological frontier. Estudios de Economía Aplicada, 37(3), 186-200.

4. Auer, B. R., \& Schuhmacher, F. (2016). Do socially (ir)responsible investments pay? New evidence from international ESG data. The Quarterly Review of Economics and Finance, 59, 51-62. https://doi.org/10.1016/j.qref.2015.07.002

5. Baird, P. L., Geylani, P. C., \& Roberts, J. A. (2012). Corporate social and financial performance reExamined: Industry effects in a linear mixed model analysis. Journal of Business Ethics, 109(3), 367388. https://doi.org/10.1007/s10551-011-1135-z

6. Balabanis, G., Phillips, H. C., \& Lyall, J. (1998). Corporate social responsibility and economic performance in the top British companies: Are they linked? European Business Review, 98(1), 2544. https://doi.org/10.1108/09555349810195529

7. Barnett, M. L., \& Salomon, R. M. (2012). Does it pay to be really good? Addressing the shape of the relationship between social and financial performance. Strategic Management Journal, 33(11), 1304-1320. https://doi.org/10.1002/smj.1980

8. Bird, R., D. Hall, A., Momentè, F., \& Reggiani, F. (2007). What corporate social responsibility activities are valued by the market? Journal of Business Ethics, 76(2), 189-206. https://doi.org/10.1007/s10551-006-9268-1

9. Brammer, S., Brooks, C., \& Pavelin, S. (2006). Corporate social performance and stock returns: UK evidence from disaggregate measures. Financial Management, 35(3), 97-116. https://doi.org/10.1111/j.1755-053X.2006.tb00149.x

10. Brooks, Chris. (2008). Introductory econometrics for finance (2nd edition). Cambridge University Press. http://dx.doi.org/10.1017/CBO9780511841644

11. Chelawat, H., \& Trivedi, I. V. (2016). The business value of ESG performance: The Indian context. Asian Journal of Business Ethics, 5(1-2), 195-210. https://doi.org/10.1007/s13520-016-0064-4 
12. Davidson, W., \& Worrell, D. (1990). A comparison and test of the use of accounting and stock market data in relating corporate social responsibility and financial performance.

13. Dobre, E., Stanila, G. O., \& Brad, L. (2015). The influence of environmental and social performance on financial performance: Evidence from Romania's listed entities. Sustainability, 7(3), 2513-2553. https://doi.org/10.3390/su7032513

14. Fauzi, H., \& Idris, K. (2009). The relationship of CSR and financial performance: New evidence from Indonesian companies. Issues in Social and Environmental Accounting, 3, 66-87.

15. Ferrero-Ferrero, I., Fernández-Izquierdo, M. Á., \& Muñoz-Torres, M. J. (2016). The effect of environmental, social and governance consistency on economic results. Sustainability, 8(10), 1005. https://doi.org/10.3390/su8101005

16. Fisher-Vanden, K., \& Thorburn, K. S. (2011). Voluntary corporate environmental initiatives and shareholder wealth. Journal of Environmental Economics and Management, 62(3), 430-445. https://doi.org/10.1016/j.jeem.2011.04.003

17. Friede, G., Busch, T., \& Bassen, A. (2015). ESG and financial performance: Aggregated evidence from more than 2000 empirical studies. Journal of Sustainable Finance \& Investment, 5(4), 210233. https://doi.org/10.1080/20430795.2015.1118917

18. Galbreath, J. (2013). ESG in focus: The Australian evidence. Journal of Business Ethics, 118(3), 529541.

19. Garcia, A. S., Mendes-Da-Silva, W., \& Orsato, R. J. (2017). Sensitive industries produce better ESG performance: Evidence from emerging markets. Journal of Cleaner Production, 150, 135-147. https://doi.org/10.1016/j.jclepro.2017.02.180

20. González-Benito, J., \& González-Benito, O. (2005). An analysis of the relationship between environmental motivations and ISO14001 certification. British Journal of Management, 16(2), 133148. https://doi.org/10.1111/j.1467-8551.2005.00436.x

21. Graves, S. B., \& Waddock, S. A. (1994). Institutional owners and corporate social performance. The Academy of Management Journal, 37(4), 1034-1046. https://doi.org/10.2307/256611

22. Griffin, J. J., \& Mahon, J. F. (1997). The corporate social performance and corporate financial performance debate: Twenty-five years of incomparable research. Business \& Society, 36(1), 5-31. https://doi.org/10.1177/000765039703600102

23. Güler, A., Aybars, A., \& Kutlu, O. (2010). Managing corporate performance: Investigating the relationship between corporate social responsibility and financial performance in emerging markets. International Journal of Productivity and Performance Management, 59(3), 229-254. https://doi.org/10.1108/17410401011023573

24. Han, J.-J., Kim, H. J., \& Yu, J. (2016). Empirical study on relationship between corporate social responsibility and financial performance in Korea. Asian Journal of Sustainability and Social Responsibility, 1(1), 61-76. https://doi.org/10.1186/s41180-016-0002-3

25. Hillman, A. J., \& Keim, G. D. (2001). Shareholder value, stakeholder management, and social issues: What's the bottom line? Strategic Management Journal, 22(2), 125-139.

26. Hoechle, D. (2007). Robust standard errors for panel regressions with cross-sectional dependence. The Stata Journal, 7(3), 281-312. https://doi.org/10.1177/1536867X0700700301

27. Horváthová, E. (2010). Does environmental performance affect financial performance? A metaanalysis. Ecological Economics, 70(1), 52-59. https://doi.org/10.1016/j.ecolecon.2010.04.004

28. Hull, C. E., \& Rothenberg, S. (2008). Firm performance: The interactions of corporate social performance with innovation and industry differentiation. Strategic Management Journal, 29(7), 781-789. https://doi.org/10.1002/smj.675

29. Karagiorgos, T. (2010). Corporate social responsibility and financial performance: An empirical analysis on Greek companies. European Research Studies Journal, XIII(4), 85-108. 
30. Mahoney, L., \& Roberts, R. W. (2007). Corporate social performance, financial performance and institutional ownership in Canadian firms. Accounting Forum, 31(3), 233-253. https://doi.org/10.1016/j.accfor.2007.05.001

31. McGuire, J. B., Sundgren, A., \& Schneeweis, T. (1988). Corporate social responsibility and firm financial performance. The Academy of Management Journal, 31(4), 854-872. https://doi.org/10.2307/256342

32. McWilliams, A., \& Siegel, D. (2000). Corporate social responsibility and financial performance: Correlation or misspecification? Strategic Management Journal, 21(5), 603-609. https://doi.org/10.1002/(SICI)1097-0266(200005)21:5<603::AID-SMJ101>3.0.CO;2-3

33. McWilliams, A., \& Siegel, D. (2001). Corporate social responsibility: A theory of the firm perspective. The Academy of Management Review, 26(1), 117-127. https://doi.org/10.2307/259398

34. Miralles-Quirós, M. M., Miralles-Quirós, J. L., \& Valente Gonçalves, L. M. (2018). The value relevance of environmental, social, and governance performance: The Brazilian case. Sustainability, 10(3), 574. https://doi.org/10.3390/su10030574

35. Miroshnychenko, I., Barontini, R., \& Testa, F. (2017). Green practices and financial performance: A global outlook. Journal of Cleaner Production, 147, 340-351. https://doi.org/10.1016/j.jclepro.2017.01.058

36. Moneva, J. M., \& Ortas, E. (2010). Corporate environmental and financial performance: A multivariate approach. Industrial Management \& Data Systems, 110(2), 193-210. https://doi.org/10.1108/02635571011020304

37. Naimy, V., \& Bou Zeidan, M. (2019). Forecasting value at risk (VAR) for emerging and developed markets. Estudios de Economía Aplicada, 37(3), 133. https://doi.org/10.25115/eea.v37i3.2778

38. Nelling, E., \& Webb, E. (2009). Corporate social responsibility and financial performance: The "virtuous circle" revisited. Review of Quantitative Finance and Accounting, 32(2), 197-209. https://doi.org/10.1007/s11156-008-0090-y

39. Nollet, J., Filis, G., \& Mitrokostas, E. (2016). Corporate social responsibility and financial performance: A non-linear and disaggregated approach. Economic Modelling, 52, 400-407. https://doi.org/10.1016/j.econmod.2015.09.019

40. Nyeadi, J. D., Ibrahim, M., \& Sare, Y. A. (2018). Corporate social responsibility and financial performance nexus: Empirical evidence from South African listed firms. Journal of Global Responsibility, 9(3), 301-328. https://doi.org/10.1108/JGR-01-2018-0004

41. Orlitzky, M., \& Benjamin, J. D. (2001). Corporate social performance and firm risk: A meta-analytic review. Business \& Society, 4O(4), 369-396. https://doi.org/10.1177/000765030104000402

42. Orlitzky, M., Schmidt, F. L., \& Rynes, S. L. (2003). Corporate social and financial performance: A meta-analysis. Organization $\quad$ Studies, 24(3), 403-441. https://doi.org/10.1177/0170840603024003910

43. Ruf, B. M., Muralidhar, K., Brown, R. M., Janney, J. J., \& Paul, K. (2001). An empirical investigation of the relationship between change in corporate social performance and financial performance: $A$ stakeholder theory perspective. Journal of Business Ethics, 32(2), 143-156.

44. Salama, A. (2005). A note on the impact of environmental performance on financial performance. Structural Change and Economic Dynamics, 16(3), 413-421. https://doi.org/10.1016/j.strueco.2004.04.005

45. Saltaji, I. M. (2013). Corporate governance and agency theory how to control agency costs. Internal Auditing and Risk Management, 32(1), 51-64.

46. Soana, M.-G. (2011). The relationship between corporate social performance and corporate financial performance in the banking sector. Journal of Business Ethics, 104(1), 133-148. 
47. SoYeon, J., Seoki, L., \& Dalbor, M. (2016). The negative synergistic effect of internationalization and corporate social responsibility on US restaurant firms' value performance. International Journal of Contemporary Hospitality Management, 28(8), 1759-1777. https://doi.org/10.1108/IJCHM-07-2014-0361

48. van Beurden, P., \& Gössling, T. (2008). The worth of values - A literature review on the relation between corporate social and financial performance. Journal of Business Ethics, 82(2), 407. https://doi.org/10.1007/s10551-008-9894-x

49. Velte, P. (2017). Does ESG performance have an impact on financial performance? Evidence from Germany. Journal of Global Responsibility, 8(2), 169-178. https://doi.org/10.1108/JGR-11-20160029

50. Waddock, S. A., \& Graves, S. B. (1997). The corporate social performance-financial performance link. Strategic Management Journal, 18(4), 303-319.

51. Xie, J., Nozawa, W., Yagi, M., Fujii, H., \& Managi, S. (2019). Do environmental, social, and governance activities improve corporate financial performance? Business Strategy and the Environment, 28(2), 286-300.

52. Zhao, C., Guo, Y., Yuan, J., Wu, M., Li, D., Zhou, Y., \& Kang, J. (2018). ESG and corporate financial performance: Empirical evidence from China's listed power generation companies. Sustainability, 10(8), 2607. https://doi.org/10.3390/su10082607 


\section{Appendices}

Appendix A. List of companies with the country of Exchange

\begin{tabular}{|c|c|}
\hline Company Name & Country of Exchange \\
\hline Aboitiz Equity Ventures Inc & Philippines \\
\hline Adani Enterprises Ltd & India \\
\hline Air China Ltd & Hong Kong \\
\hline Airasia Group Bhd & Malaysia \\
\hline Airports of Thailand PCL & Thailand \\
\hline Airtac International Group & Taiwan \\
\hline Alliance Global Group Inc & Philippines \\
\hline AviChina Industry \& Technology Co Ltd & Hong Kong \\
\hline Beijing Capital International Airport Co Ltd & Hong Kong \\
\hline Berjaya Corporation Bhd & Malaysia \\
\hline Bharat Heavy Electricals Ltd & India \\
\hline BTS Group Holdings PCL & Thailand \\
\hline China Airlines Ltd & Taiwan \\
\hline China Communications Construction Co Ltd & Hong Kong \\
\hline China Conch Venture Holdings Ltd & Hong Kong \\
\hline China High Speed Transmission Equipment Group Co Ltd & Hong Kong \\
\hline China International Marine Containers Group Co Ltd & Hong Kong \\
\hline China Merchants Port Holdings Co Ltd & Hong Kong \\
\hline China Railway Construction Corp Ltd & Hong Kong \\
\hline China Railway Group Ltd & Hong Kong \\
\hline China Southern Airlines Co Ltd & Hong Kong \\
\hline China State Construction International Holdings Ltd & Hong Kong \\
\hline CJ Corp & Korea; Republic (S. Korea) \\
\hline COSCO SHIPPING Development Co Ltd & Hong Kong \\
\hline COSCO Shipping Energy Transportation Co Ltd & Hong Kong \\
\hline COSCO SHIPPING Holdings Co Ltd & Hong Kong \\
\hline COSCO SHIPPING Ports Ltd & Hong Kong \\
\hline CRRC Corp Ltd & Hong Kong \\
\hline CTCI Corp & Taiwan \\
\hline Daelim Industrial Co Ltd & Korea; Republic (S. Korea) \\
\hline Daewoo Engineering \& Construction Co Ltd & Korea; Republic (S. Korea) \\
\hline Daewoo Shipbuilding \& Marine Engineering Co Ltd & Korea; Republic (S. Korea) \\
\hline DMCI Holdings Inc & Philippines \\
\hline Dongfang Electric Corp Ltd & Hong Kong \\
\hline Doosan Co Ltd & Korea; Republic (S. Korea) \\
\hline Doosan Heavy Industries \& Construction Co Ltd & Korea; Republic (S. Korea) \\
\hline Doosan Infracore Co Ltd & Korea; Republic (S. Korea) \\
\hline Eva Airways Corp & Taiwan \\
\hline
\end{tabular}




\begin{tabular}{|c|c|}
\hline Evergreen Marine Corp Taiwan Ltd & Taiwan \\
\hline Far Eastern New Century Corp & Taiwan \\
\hline Fosun International Ltd & Hong Kong \\
\hline Gamuda Bhd & Malaysia \\
\hline GMR Infrastructure Ltd & India \\
\hline GS Engineering \& Construction Corp & Korea; Republic (S. Korea) \\
\hline Haitian International Holdings Ltd & Hong Kong \\
\hline Hanjin Heavy Industries \& Construction Co Ltd & Korea; Republic (S. Korea) \\
\hline Hanwha AeroSpace Co Ltd & Korea; Republic (S. Korea) \\
\hline Hanwha Corp & Korea; Republic (S. Korea) \\
\hline HDC Holdings Co Ltd & Korea; Republic (S. Korea) \\
\hline Hiwin Technologies Corp & Taiwan \\
\hline Hyosung Corp & Korea; Republic (S. Korea) \\
\hline Hyundai Engineering \& Construction Co Ltd & Korea; Republic (S. Korea) \\
\hline Hyundai Glovis Co Ltd & Korea; Republic (S. Korea) \\
\hline Hyundai Heavy Industries Co Ltd & Korea; Republic (S. Korea) \\
\hline Hyundai Merchant Marine Co Ltd & Korea; Republic (S. Korea) \\
\hline Hyundai Mipo Dockyard Co Ltd & Korea; Republic (S. Korea) \\
\hline IJM Corporation Bhd & Malaysia \\
\hline International Container Terminal Services Inc & Philippines \\
\hline Jaiprakash Associates Ltd & India \\
\hline Jasa Marga (Persero) Tbk PT & Indonesia \\
\hline JG Summit Holdings Inc & Philippines \\
\hline Jiangsu Expressway Co Ltd & Hong Kong \\
\hline JVM Co Ltd & Korea; Republic (S. Korea) \\
\hline KCC Corp & Korea; Republic (S. Korea) \\
\hline KEPCO Plant Service \& Engineering Co Ltd & Korea; Republic (S. Korea) \\
\hline Korea Aerospace Industries Ltd & Korea; Republic (S. Korea) \\
\hline Korean Air Lines Co Ltd & Korea; Republic (S. Korea) \\
\hline Larsen \& Toubro Ltd & India \\
\hline LG Corp & Korea; Republic (S. Korea) \\
\hline Lonking Holdings Ltd & Hong Kong \\
\hline LS Corp & Korea; Republic (S. Korea) \\
\hline LS Industrial Systems Co Ltd & Korea; Republic (S. Korea) \\
\hline Malaysia Airports Holdings Bhd & Malaysia \\
\hline Metallurgical Corporation of China Ltd & Hong Kong \\
\hline Misc Bhd & Malaysia \\
\hline MMC Corporation Bhd & Malaysia \\
\hline Pan Ocean Co Ltd & Korea; Republic (S. Korea) \\
\hline Posco Daewoo Corp & Korea; Republic (S. Korea) \\
\hline S1 Corp & Korea; Republic (S. Korea) \\
\hline
\end{tabular}




\begin{tabular}{|c|c|}
\hline Samsung C\&T Corp & Korea; Republic (S. Korea) \\
\hline Samsung Engineering Co Ltd & Korea; Republic (S. Korea) \\
\hline Samsung Heavy Industries Co Ltd & Korea; Republic (S. Korea) \\
\hline San Miguel Corp & Philippines \\
\hline Sany Heavy Equipment International Holdings Company Ltd & Hong Kong \\
\hline Shanghai Electric Group Co Ltd & Hong Kong \\
\hline Shanghai Industrial Holdings Ltd & Hong Kong \\
\hline Siemens Ltd & India \\
\hline Sime Darby Bhd & Malaysia \\
\hline Sinopec Engineering Group Co Ltd & Hong Kong \\
\hline Sinotrans Ltd & Hong Kong \\
\hline Sinotruk Hong Kong Ltd & Hong Kong \\
\hline SK Holdings Co Ltd & Korea; Republic (S. Korea) \\
\hline SK Networks Co Ltd & Korea; Republic (S. Korea) \\
\hline SM Investments Corp & Philippines \\
\hline Taiwan Glass Ind Corp & Taiwan \\
\hline TECO Electric \& Machinery Co Ltd & Taiwan \\
\hline Thai Airways International PCL & Thailand \\
\hline U-Ming Marine Transport Corp & Taiwan \\
\hline Walsin Lihwa Corp & Taiwan \\
\hline Wan Hai Lines Ltd & Taiwan \\
\hline Weichai Power Co Ltd & Hong Kong \\
\hline Westports Holdings Bhd & Malaysia \\
\hline Yang Ming Marine Transport Corp & Taiwan \\
\hline Zhejiang Expressway Co Ltd & Hong Kong \\
\hline Zhuzhou CRRC Times Electric Co Ltd & Hong Kong \\
\hline Zoomlion Heavy Industry Science and Technology Co Ltd & Hong Kong \\
\hline
\end{tabular}

Appendix B. Descriptive statistics for independent variables

\begin{tabular}{|l|c|c|c|c|c|c|c|c|c|}
\hline & \multicolumn{3}{|c}{ ESG } & \multicolumn{2}{c|}{ ENV } & \multicolumn{2}{c|}{ SOC } & \multicolumn{2}{c|}{ GOV } \\
\hline Year & N & Mean & SD & Mean & SD & Mean & SD & Mean & SD \\
\hline $\mathbf{2 0 1 1}$ & 73 & 37.754521 & 15.91 & 37.146027 & 20.29 & 32.830959 & 20.02 & 45.407945 & 21.32 \\
\hline $\mathbf{2 0 1 2}$ & 98 & 39.436837 & 16.73 & 40.158061 & 22.51 & 37.393061 & 22.41 & 47.799082 & 21.47 \\
\hline $\mathbf{2 0 1 3}$ & 103 & 39.071262 & 16.26 & 41.241359 & 22.34 & 37.624369 & 22.46 & 48.16301 & 22.54 \\
\hline $\mathbf{2 0 1 4}$ & 108 & 38.983333 & 15.24 & 42.410926 & 22.31 & 40.393056 & 22.78 & 47.617407 & 21.56 \\
\hline $\mathbf{2 0 1 5}$ & 105 & 43.704762 & 17.76 & 47.453238 & 21.65 & 42.393143 & 23.67 & 49.923429 & 21.96 \\
\hline $\mathbf{2 0 1 6}$ & 107 & 43.859626 & 17.47 & 53.091682 & 20.59 & 47.606822 & 24.12 & 47.73514 & 20.22 \\
\hline $\mathbf{2 0 1 7}$ & $\mathbf{2 0}$ & 49.035 & 17.29 & 57.132083 & 19.64 & 50.927778 & 23.07 & 46.787917 & 21.37 \\
\hline Overall & $\mathbf{6 6 6}$ & $\mathbf{4 1 . 5 4 3 4 3}$ & $\mathbf{1 6 . 9 7}$ & $\mathbf{4 5 . 4 2 3 8 7 4}$ & $\mathbf{2 2 . 3 2}$ & $\mathbf{4 1 . 3 0 7 7 3 3}$ & $\mathbf{2 3 . 3 2}$ & $\mathbf{4 7 . 7 7 9 1 4 4}$ & $\mathbf{2 1 . 4 5}$ \\
\hline Capital Goods & $\mathbf{4 5 9}$ & $\mathbf{4 0 . 3 1 4 7 9}$ & $\mathbf{1 7 . 8 4}$ & $\mathbf{4 4 . 7 4 3 3 8}$ & $\mathbf{2 3 . 0 7}$ & $\mathbf{3 9 . 0 6 3 2 2}$ & $\mathbf{2 2 . 6 5}$ & $\mathbf{4 8 . 1 2 8 5 2}$ & $\mathbf{2 1 . 9 6}$ \\
\hline Transportation & $\mathbf{1 9 2}$ & $\mathbf{4 4 . 6 4 1 5 1}$ & $\mathbf{1 3 . 9 8}$ & $\mathbf{4 6 . 4 1 8 1 8}$ & $\mathbf{2 0 . 4 9}$ & $\mathbf{4 7 . 1 7 0 0 5}$ & $\mathbf{2 3 . 9 6}$ & $\mathbf{4 8 . 4 0 2 0 3}$ & $\mathbf{1 9 . 5 8}$ \\
\hline
\end{tabular}


Appendix C. Descriptive statistics for dependent and control variables

\begin{tabular}{|l|c|c|c|c|c|}
\hline Variables & Mean & SD & Min & Max & N \\
\hline \multicolumn{7}{|c|}{ Panel A: CFP } \\
\hline ROA (\%) & 3.552285 & 4.718471 & -12.2158 & 25.55664 & 666 \\
\hline ROE (\%) & 7.018712 & 14.27877 & -97.78508 & 95.43684 & 666 \\
\hline RET (\%) & 25.39723 & 23.51469 & .0017066 & 167.3557 & 592 \\
\hline PB & 1.58254 & 1.343817 & .0903457 & 9.424688 & 613 \\
\hline \multicolumn{7}{|c|}{ Panel B: Control Variables } \\
\hline SIZE & 22.74234 & 1.134914 & 18.7439 & 25.7354 & 666 \\
\hline LEV & .3177307 & .1734772 & 0 & .7801498 & 666 \\
\hline R\&D (\%) & 1.448534 & 1.589565 & .0017579 & 7.823741 & 278 \\
\hline
\end{tabular}

Appendix D. Pearson correlation of explanatory variables

\begin{tabular}{|l|c|c|c|c|c|c|}
\hline & ESG & ENV & SOC & GOV & SIZE & LEV \\
\hline ESG & 1.0000 & & & & & \\
\hline ENV & 0.7055 & 1.0000 & & & & \\
\hline SOC & 0.8075 & 0.6979 & 1.0000 & & & \\
\hline GOV & 0.5544 & 0.1625 & 0.2913 & 1.0000 & & \\
\hline SIZE & 0.1481 & 0.1819 & 0.1356 & 0.2853 & 1.0000 & \\
\hline LEV & 0.1297 & 0.2032 & 0.1876 & -0.0571 & 0.1827 & 1.0000 \\
\hline
\end{tabular}

Appendix E. Wooldridge autocorrelation test for all regression equations

\begin{tabular}{|l|c|c|c|c|c|c|c|c|}
\hline & \multicolumn{2}{|c|}{ ROA } & \multicolumn{2}{c|}{ ROE } & \multicolumn{2}{c|}{ RET } & \multicolumn{2}{c|}{ PB } \\
\hline & F & P-value & F & P-value & F & P-value & F & P-value \\
\hline Model 1 & 55.225 & 0.000 & 29.250 & 0.000 & 34.521 & 0.000 & 11.145 & 0.0012 \\
\hline Model 2 & 55.130 & 0.000 & 29.192 & 0.000 & 34.721 & 0.000 & 11.210 & 0.0012 \\
\hline Model 3 & 54.214 & 0.000 & 29.742 & 0.000 & 34.920 & 0.000 & 11.480 & 0.0010 \\
\hline Model 4 & 51.511 & 0.000 & 32.022 & 0.000 & 35.600 & 0.000 & 11.677 & 0.0009 \\
\hline
\end{tabular}

${ }^{\star}$ All regressions include industry dummies

Appendix F. Hausman test summary

\begin{tabular}{|l|c|c|c|c|c|c|c|c|}
\hline \multirow{2}{*}{} & \multicolumn{2}{|c}{ ROA } & \multicolumn{2}{c|}{ ROE } & \multicolumn{2}{c|}{ RET } & \multicolumn{2}{c|}{ PB } \\
\cline { 2 - 9 } & Chi2 & P-value & Chi2 & P-value & Hausman & P-value & Hausman & P-value \\
\hline Model 1 & 330.76 & 0.000 & 494.02 & 0.000 & 99.82 & 0.000 & 310.41 & 0.000 \\
\hline Model 2 & 316.85 & 0.000 & 442.57 & 0.000 & 100.23 & 0.000 & 311.92 & 0.000 \\
\hline Model 3 & 330.97 & 0.000 & 507.67 & 0.000 & 113.94 & 0.000 & 307.45 & 0.000 \\
\hline Model 4 & 323.53 & 0.000 & 473.11 & 0.000 & 106.01 & 0.000 & 312.65 & 0.000 \\
\hline
\end{tabular}

Appendix G. Pesaran test summary

\begin{tabular}{|l|c|c|c|c|c|c|c|c|}
\hline \multirow{2}{*}{} & \multicolumn{2}{|c|}{ ROA } & \multicolumn{2}{c|}{ ROE } & \multicolumn{2}{c|}{ RET } & \multicolumn{2}{c|}{ PB } \\
\cline { 2 - 9 } & Pesaran & P-value & Pesaran & P-value & Pesaran & P-value & Pesaran & P-value \\
\hline Model 1 & 9.780 & 0.000 & 9.736 & 0.000 & 9.340 & 0.000 & 14.903 & 0.000 \\
\hline Model 2 & 10.031 & 0.000 & 10.059 & 0.000 & 11.021 & 0.000 & 14.624 & 0.000 \\
\hline Model 3 & 9.311 & 0.000 & 10.024 & 0.000 & 0.704 & 0.482 & 17.093 & 0.000 \\
\hline Model 4 & 11.928 & 0.000 & 12.632 & 0.000 & 0.785 & 0.433 & 17.861 & 0.000 \\
\hline
\end{tabular}


Appendix H Table 1. Results for ESG vs ROA regression

\begin{tabular}{|c|c|c|c|c|c|c|c|c|}
\hline & \multicolumn{2}{|c|}{ Model 1} & \multicolumn{2}{|c|}{ Model 2} & \multicolumn{2}{|c|}{ Model 3} & \multicolumn{2}{|c|}{ Model 4} \\
\hline & Coeff & P-value & Coeff & P-value & Coeff & P-value & Coeff & P-value \\
\hline$E S G_{i, t-1}$ & -.015469 & 0.316 & 0.010386 & 0.699 & & & & \\
\hline$E_{S G}{ }^{2} i,-1$ & & & -.00029 & 0.489 & & & & \\
\hline \multicolumn{9}{|c|}{ ESG Pillar } \\
\hline $\mathrm{ENV}_{\mathrm{i}, \mathrm{t}-1}$ & & & & & .0039992 & 0.467 & -.098943 & $0.000 * * *$ \\
\hline $\mathrm{SOC}_{\mathrm{i}, \mathrm{t}-1}$ & & & & & -.011311 & 0.233 & .0623712 & $0.000 * * *$ \\
\hline $\mathrm{GOV}_{\mathrm{i}, \mathrm{t}-1}$ & & & & & -.008626 & $0.019^{\star *}$ & -.001333 & 0.963 \\
\hline$E N V^{2} i, t-1$ & & & & & & & .0010823 & $0.000^{* * *}$ \\
\hline $\operatorname{SOC}^{2} \mathrm{i}, \mathrm{t}-1$ & & & & & & & -.000792 & $0.000^{* * *}$ \\
\hline $\mathrm{GOV}^{2} \mathrm{i}, \mathrm{t}-1$ & & & & & & & -.000065 & 0.834 \\
\hline \multicolumn{9}{|c|}{ Control Variables } \\
\hline$R O A_{i, t-1}$ & .0758624 & 0.180 & .0762158 & 0.173 & .07528 & 0.175 & .0756829 & 0.129 \\
\hline SIZE $\mathrm{E}_{\mathrm{i}, \mathrm{t}-1}$ & -1.92194 & $0.000^{* * *}$ & -1.91029 & $0.000^{* * *}$ & -1.92471 & $0.000^{* * *}$ & -1.85107 & $0.000^{* * *}$ \\
\hline $\operatorname{LEV}_{\mathrm{i}, \mathrm{t}-1}$ & -4.27117 & 0.179 & -4.31654 & 0.160 & -4.44022 & 0.147 & -4.39404 & 0.144 \\
\hline \multicolumn{9}{|c|}{ Industry Dummies } \\
\hline $\begin{array}{l}\text { Industry } \\
\text { Dummies }\end{array}$ & \multicolumn{2}{|c|}{ Included } & \multicolumn{2}{|c|}{ Included } & \multicolumn{2}{|c|}{ Included } & \multicolumn{2}{|c|}{ Included } \\
\hline Cons & 48.66647 & $0.000^{* * *}$ & 47.92351 & $0.000^{* * *}$ & 48.8454 & $0.000^{* * *}$ & 47.62757 & $0.000^{\star * \star}$ \\
\hline F-Statistic & 90.57 & & 76.90 & & 109.15 & & 80.63 & \\
\hline Nb. Obs & 554 & & 554 & & 554 & & 554 & \\
\hline
\end{tabular}

Source: Author's Own calculation

Notes: This table provides the results of Driscoll-Kray standard errors estimation using ROA as the dependent variable. All data are reported in annual frequency for the period 2011 through $2017 .{ }^{* * *},{ }^{* *}$, and ${ }^{*}$ specify significance at $1 \%, 5 \%$, and $10 \%$ levels, respectively.

Appendix H Table 2. Results for ESG vs ROE regression

\begin{tabular}{|c|c|c|c|c|c|c|c|c|}
\hline & \multicolumn{2}{|c|}{ Model 1} & \multicolumn{2}{|c|}{ Model 2} & \multicolumn{2}{|c|}{ Model 3} & \multicolumn{2}{|c|}{ Model 4} \\
\hline & Coeff & P-value & Coeff & P-value & Coeff & P-value & Coeff & P-value \\
\hline$E S G_{i, t-1}$ & -.030501 & 0.364 & .046065 & 0.680 & & & & \\
\hline $\mathrm{ESG}^{2} \mathrm{i}, \mathrm{t}-1$ & & & -.000859 & 0.534 & & & & \\
\hline \multicolumn{9}{|c|}{ ESG Pillar } \\
\hline $\mathrm{ENV}_{\mathrm{i}, \mathrm{t}-1}$ & & & & & .0041358 & 0.813 & -.271227 & $0.000^{* * *}$ \\
\hline $\mathrm{SOC}_{\mathrm{i}, \mathrm{t}-1}$ & & & & & -.022858 & 0.334 & .1732855 & $0.000^{* * *}$ \\
\hline GOV $_{i, t-1}$ & & & & & -.002474 & 0.773 & .0624973 & 0.587 \\
\hline $\mathrm{ENV}^{2} \mathrm{i}, \mathrm{t}-1$ & & & & & & & .0028919 & $0.002^{\star * \star}$ \\
\hline $\operatorname{SOC}^{2} \mathrm{i}, \mathrm{t}-1$ & & & & & & & -.002104 & $0.000^{* * *}$ \\
\hline $\mathrm{GOV}^{2}{ }_{\mathrm{i}, \mathrm{t}-1}$ & & & & & & & -.000648 & 0.579 \\
\hline \multicolumn{9}{|c|}{ Control Variables } \\
\hline $\mathrm{ROE}_{\mathrm{i}, \mathrm{t}-1}$ & .0198987 & 0.809 & .0207021 & 0.801 & .0192221 & 0.813 & .0220263 & 0.774 \\
\hline SIZE $E_{i, t-1}$ & -5.49448 & $0.000^{* * *}$ & -5.46387 & $0.000^{* * *}$ & -5.49206 & $0.000^{* * *}$ & -5.28613 & $0.000^{* * *}$ \\
\hline LEV $_{\mathrm{i}, \mathrm{t}-1}$ & -3.20966 & 0.704 & -3.32374 & 0.683 & -3.8008 & 0.651 & -3.62329 & 0.659 \\
\hline
\end{tabular}




\begin{tabular}{|l|c|c|c|c|c|c|c|c|}
\hline \multicolumn{9}{|c|}{ Industry Dummies } \\
\hline $\begin{array}{l}\text { Industry } \\
\text { Dummies }\end{array}$ & \multicolumn{2}{|c|}{ Included } & \multicolumn{2}{c|}{ Included } & \multicolumn{2}{c|}{ Included } & \multicolumn{3}{c|}{ Included } \\
\hline Cons & 133.1217 & $0.000^{\star * *}$ & 131.0011 & $0.000^{* * *}$ & 132.8706 & $0.000^{* * *}$ & 128.5209 & $0.000^{* * *}$ \\
\hline F-Statistic & 38.12 & & 67.60 & & 12.08 & & 39.03 & \\
\hline Nb. Obs & 554 & & 554 & & 554 & & 554 & \\
\hline
\end{tabular}

Source: Author's Own calculation

Notes: This table provides the results of Driscoll-Kray standard errors estimation using ROE as the dependent variable. All data are reported in annual frequency for the period 2011 through $2017 .{ }^{* * *}$, ${ }^{* *}$, and ${ }^{*}$ specify significance at $1 \%, 5 \%$, and $10 \%$ levels, respectively.

Appendix H Table 3. Results for ESG vs RET regression

\begin{tabular}{|c|c|c|c|c|c|c|c|c|}
\hline & \multicolumn{2}{|c|}{ Model 1} & \multicolumn{2}{|c|}{ Model 2} & \multicolumn{2}{|c|}{ Model 3} & \multicolumn{2}{|c|}{ Model 4} \\
\hline & Coeff & P-value & Coeff & P-value & Coeff & P-value & Coeff & P-value \\
\hline$E S G_{i, t-1}$ & 0304604 & 0.627 & .295884 & $0.010^{\star *}$ & & & & \\
\hline$E G^{2} i,-1$ & & & -.002944 & $0.006^{\star \star \star}$ & & & & \\
\hline \multicolumn{9}{|c|}{ ESG Pillar } \\
\hline $\mathrm{ENV}_{\mathrm{i}, \mathrm{t}-1}$ & & & & & .0175558 & 0.880 & -.016091 & 0.971 \\
\hline $\mathrm{SOC}_{\mathrm{i},-1-1}$ & & & & & .3058515 & $0.023^{* *}$ & .3587382 & 0.323 \\
\hline $\mathrm{GOV}_{\mathrm{i},-1-1}$ & & & & & 1965907 & $0.050^{*}$ & -649701 & 0.110 \\
\hline $\mathrm{ENV}^{2} \mathrm{i}, \mathrm{t}-1$ & & & & & & & .0004379 & 0.923 \\
\hline $\operatorname{SOC}^{2} \mathrm{it,-1}$ & & & & & & & -.000626 & 0.854 \\
\hline $\mathrm{GOV}^{2}{ }_{\mathrm{i}, \mathrm{t}-\mathrm{1}}$ & & & & & & & .0046316 & 0.227 \\
\hline \multicolumn{9}{|c|}{ Control Variables } \\
\hline $\mathrm{RET}_{\mathrm{i}, \mathrm{t}-1}$ & -.168552 & $0.003^{\star \star \star}$ & -.169318 & $0.003^{* * *}$ & -.167905 & $0.000^{\star \star \star \star}$ & -.171432 & $0.000^{\star \star \star}$ \\
\hline SIZE & -14.8365 & $0.000^{\star * *}$ & -14.6856 & $0.000^{* * *}$ & -17.4280 & $0.000^{\star * *}$ & -17.6974 & $0.000^{\star * *}$ \\
\hline $\operatorname{LEV}_{\mathrm{i}, \mathrm{t}-1}$ & 3.64913 & 0.877 & 2.821004 & 0.902 & -15.4717 & 0.616 & 16.62615 & 0.599 \\
\hline \multicolumn{9}{|c|}{ Industry Dummies } \\
\hline $\begin{array}{l}\text { Industry } \\
\text { Dummies }\end{array}$ & \multicolumn{2}{|c|}{ Included } & \multicolumn{2}{|c|}{ Included } & \multicolumn{2}{|c|}{ Included } & \multicolumn{2}{|c|}{ Included } \\
\hline Cons & 363.902 & $0.000^{\star \star \star}$ & 355.6444 & $0.000^{\star \star *}$ & 416.4959 & $0.000^{\star \star \star}$ & 430.8864 & $0.000^{\star \star *}$ \\
\hline F-Statistic & 26.69 & & 78.78 & & 7.87 & & 6.07 & \\
\hline Nb. Obs & 480 & & 480 & & 480 & & 480 & \\
\hline
\end{tabular}

Source: Author's Own calculation

Notes: This table provides the results of Driscoll-Kray standard errors estimation for Models 1 and 2 and the fixed effects with robust and clustered standard errors for Models 3 and 4, using RET as the dependent variable. All data are reported in annual frequency for the period 2011 through 2017 . ${ }^{* *},{ }^{* *}$, and ${ }^{*}$ specify significance at $1 \%, 5 \%$, and $10 \%$ levels, respectively. 
Appendix H Table 4. Results for ESG vs PB regression

\begin{tabular}{|c|c|c|c|c|c|c|c|c|}
\hline & \multicolumn{2}{|c|}{ Model 1} & \multicolumn{2}{|c|}{ Model 2} & \multicolumn{2}{|c|}{ Model 3} & \multicolumn{2}{|c|}{ Model 4} \\
\hline & Coeff & P-value & Coeff & P-value & Coeff & P-value & Coeff & P-value \\
\hline$E S G_{i, t-1}$ & -.005672 & $0.000^{* * *}$ & -.023257 & $0.010^{* *}$ & & & & \\
\hline $\mathrm{ESG}^{2} \mathrm{i,t-1}$ & & & .000195 & $0.062^{\star *}$ & & & & \\
\hline \multicolumn{9}{|c|}{ ESG Pillar } \\
\hline $\mathrm{ENV}_{\mathrm{i}, \mathrm{t}-1}$ & & & & & -.005922 & 0.102 & -.012905 & 0.175 \\
\hline $\mathrm{SOC}_{\mathrm{i}, \mathrm{t}-1}$ & & & & & .001095 & 0.687 & -.008069 & 0.281 \\
\hline $\mathrm{GOV}_{\mathrm{i}, \mathrm{t}-1}$ & & & & & -.002344 & $0.004^{\star \star \star}$ & -.016028 & $0.000^{* * *}$ \\
\hline $\mathrm{ENV}^{2} \mathrm{i}, \mathrm{t}-1$ & & & & & & & .0000807 & 0.258 \\
\hline $\operatorname{SOC}^{2}, \mathrm{t}-1$ & & & & & & & .0001047 & 0.181 \\
\hline $\mathrm{GOV}^{2} \mathrm{it-1}$ & & & & & & & .0001448 & $0.000^{* * *}$ \\
\hline \multicolumn{9}{|c|}{ Control Variables } \\
\hline $\mathrm{PB}_{\mathrm{i}, \mathrm{t}-1}$ & -.044253 & $0.637^{* \star *}$ & -.047202 & 0.616 & -.045156 & 0.630 & -.04869 & 0.605 \\
\hline$S I Z E_{i, t-1}$ & -.664498 & $0.000^{* * *}$ & -.672788 & $0.000^{* * *}$ & -.640062 & $0.000^{* * *}$ & -.656687 & $0.000^{* * *}$ \\
\hline LEV $_{\mathrm{i}, \mathrm{t}-1}$ & -.874972 & 0.349 & -.878265 & 0.358 & -.857693 & 0.358 & -.827572 & 0.396 \\
\hline \multicolumn{9}{|c|}{ Industry Dummies } \\
\hline $\begin{array}{l}\text { Industry } \\
\text { Dummies }\end{array}$ & \multicolumn{2}{|c|}{ Included } & \multicolumn{2}{|c|}{ Included } & \multicolumn{2}{|c|}{ Included } & \multicolumn{2}{|c|}{ Included } \\
\hline Cons & 17.24522 & $0.000^{\star \star *}$ & 17.77988 & $0.000^{* \star *}$ & 16.77954 & $0.000^{\star \star \star}$ & 17.66805 & $0.000^{\star \star *}$ \\
\hline F-Statistic & 267.62 & & 180.02 & & 21.67 & & 23.83 & \\
\hline $\mathrm{Nb}$. Obs & 496 & & 496 & & 496 & & 496 & \\
\hline
\end{tabular}

Source: Author's Own calculation

Notes: This table provides the results of Driscoll-Kray standard errors estimation using PB as the dependent variable. All data are reported in annual frequency for the period 2011 through $2017 .{ }^{* * *},{ }^{* *}$, and * specify significance at $1 \%, 5 \%$, and $10 \%$ levels, respectively.

Appendix I Table 1. Results for ESG vs ROA regression by industry

\begin{tabular}{|l|c|c|c|c|c|c|c|c|}
\hline & \multicolumn{4}{|c|}{ Capital Goods } & \multicolumn{3}{c|}{ Transportation } \\
\hline & \multicolumn{2}{|c|}{ Model 1 } & \multicolumn{2}{c|}{ Model 2 } & \multicolumn{2}{c|}{ Model 1 } & \multicolumn{2}{c|}{ Model 2 } \\
\hline & Coeff & P-value & Coeff & P-value & Coeff & P-value & Coeff & P-value \\
\hline ESG $_{i,-1}$ & -.011698 & 0.419 & -.03052 & 0.554 & -.0089816 & 0.640 & .18012 & $0.000^{* * *}$ \\
\hline ESG $^{2}, \mathrm{t}-1$ & & & .000207 & 0.752 & & & -.00218 & $0.000^{* * *}$ \\
\hline ROA $_{\mathrm{i}, \mathrm{t}-1}$ & .1218919 & $0.063^{*}$ & .121935 & $0.064^{*}$ & -.097251 & $0.040^{* *}$ & -.08004 & 0.104 \\
\hline SIZE $_{\mathrm{i}, \mathrm{t}-1}$ & -1.701571 & $0.000^{* * *}$ & -1.71175 & $0.000^{* * *}$ & -4.217842 & $0.000^{* * *}$ & -4.1308 & $0.000^{* * *}$ \\
\hline LEV $_{\mathrm{i}, \mathrm{t}-1}$ & -5.883787 & $0.059^{*}$ & -5.93782 & $0.070^{*}$ & 1.008397 & 0.781 & -.83613 & 0.816 \\
\hline Cons & 43.76908 & $0.000^{* * *}$ & 44.3744 & $0.000^{* * *}$ & 98.36358 & $0.000^{* * *}$ & 93.416 & $0.000^{* * *}$ \\
\hline F-Statistic & 124.53 & & 119.22 & & 92.99 & & 174.67 & 159 \\
\hline Nb. Obs & 383 & & 383 & & 159 & & & \\
\hline
\end{tabular}

Notes: This table provides the results of Driscoll-Kray standard errors estimation using ROA as the dependent variable. All data are reported in annual frequency for the period 2011 through $2017 .{ }^{* \star \star}$, ${ }^{\star \star}$, and ${ }^{*}$ specify significance at $1 \%, 5 \%$, and $10 \%$ levels, respectively. 
Appendix I Table 2. Results for ESG vs ROE regression by industry

\begin{tabular}{|c|c|c|c|c|c|c|c|c|}
\hline & \multicolumn{4}{|c|}{ Capital Goods } & \multicolumn{4}{|c|}{ Transportation } \\
\hline & \multicolumn{2}{|c|}{ Model 1} & \multicolumn{2}{|c|}{ Model 2} & \multicolumn{2}{|c|}{ Model 1} & \multicolumn{2}{|c|}{ Model 2} \\
\hline & Coeff & P-value & Coeff & P-value & Coeff & P-value & Coeff & P-value \\
\hline$E S G_{i, t-1}$ & -.0137438 & 0.740 & .0005081 & 0.998 & -.0339022 & 0.186 & .2952846 & 0.182 \\
\hline $\mathrm{ESG}^{2} \mathrm{i}, \mathrm{t}-1$ & & & -.0001566 & 0.940 & & & -.0037987 & 0.108 \\
\hline $\mathrm{ROE}_{\mathrm{i}, \mathrm{t}-1}$ & .0187949 & 0.841 & .0189228 & 0.834 & .0041753 & 0.968 & .010978 & 0.915 \\
\hline$S I Z E_{i, t-1}$ & -4.951174 & $0.000^{\star \star *}$ & -4.944116 & $0.000^{* * *}$ & -10.84969 & $0.000^{\star \star *}$ & -10.74426 & $0.000^{* * *}$ \\
\hline LEV $_{\mathrm{i}, \mathrm{t}-1}$ & -9.247125 & 0.121 & -9.196623 & 0.155 & 9.547163 & 0.159 & 6.264955 & 0.386 \\
\hline Cons & 123.0029 & $0.000^{* * *}$ & 122.5554 & $0.000^{* * *}$ & 245.8697 & $0.000^{* * *}$ & 238.3794 & $0.000^{* * *}$ \\
\hline F-Statistic & 14.42 & & 86.07 & & 53.72 & & 79.72 & \\
\hline $\mathrm{Nb}$. Obs & 383 & & 383 & & 159 & & 159 & \\
\hline
\end{tabular}

Appendix I Table 3. Results for ESG vs RET regression by industry

\begin{tabular}{|c|c|c|c|c|c|c|c|c|}
\hline & \multicolumn{4}{|c|}{ Capital Goods } & \multicolumn{4}{|c|}{ Transportation } \\
\hline & \multicolumn{2}{|c|}{ Model 1} & \multicolumn{2}{|c|}{ Model 2} & \multicolumn{2}{|c|}{ Model 1} & \multicolumn{2}{|c|}{ Model 2} \\
\hline & Coeff & P-value & Coeff & P-value & Coeff & P-value & Coeff & P-value \\
\hline$E S G_{i, t-1}$ & .0937493 & 0.114 & .2117875 & 0.116 & -.1283107 & $0.088^{*}$ & .4475376 & 0.152 \\
\hline $\mathrm{ESG}^{2} \mathrm{i}, \mathrm{t}-1$ & & & -.0012839 & 0.191 & & & -.00656 & 0.124 \\
\hline $\mathrm{RET}_{\mathrm{i}, \mathrm{t}-1}$ & -.1966339 & $0.051^{*}$ & -.1978968 & $0.051^{*}$ & -.1657499 & $0.000^{* * *}$ & -.1620525 & $0.000^{* * *}$ \\
\hline SIZE $\mathrm{i}_{\mathrm{i}, \mathrm{t}-1}$ & -14.21125 & $0.000^{* * *}$ & -14.14169 & $0.000^{* * *}$ & -14.19576 & 0.105 & -13.66692 & 0.137 \\
\hline LEV $_{i, t-1}$ & -39.03343 & $0.096^{*}$ & -38.91102 & $0.094^{*}$ & 51.72316 & $0.062^{*}$ & 45.98493 & $0.074^{*}$ \\
\hline Cons & 362.9248 & $0.000^{* * *}$ & 359.0665 & $0.000^{\star * *}$ & 332.4407 & $0.075^{\star}$ & 311.2798 & 0.114 \\
\hline F-Statistic & & & 298.02 & & 118.61 & & 87.48 & \\
\hline Nb. Obs & 332 & & 332 & & 136 & & 136 & \\
\hline
\end{tabular}

Notes: This table provides the results of Driscoll-Kray standard errors estimation using RET as the dependent variable. All data are reported in annual frequency for the period 2011 through $2017 .{ }^{* * *},{ }^{* *}$, and ${ }^{*}$ specify significance at $1 \%, 5 \%$, and $10 \%$ levels, respectively.

Appendix I Table 4. Results for ESG vs PB regression by industry

\begin{tabular}{|c|c|c|c|c|c|c|c|c|}
\hline & \multicolumn{4}{|c|}{ Capital Goods } & \multicolumn{4}{|c|}{ Transportation } \\
\hline & \multicolumn{2}{|c|}{ Model 1} & \multicolumn{2}{|c|}{ Model 2} & \multicolumn{2}{|c|}{ Model 1} & \multicolumn{2}{|c|}{ Model 2} \\
\hline & Coeff & P-value & Coeff & P-value & Coeff & P-value & Coeff & P-value \\
\hline $\mathrm{ESG}_{\mathrm{i}, \mathrm{t}-1}$ & -.0032351 & $0.006^{* * *}$ & -.0233638 & $0.001^{* * *}$ & -.0113235 & $0.000^{* * *}$ & .0187353 & 0.331 \\
\hline$E_{S G}^{2} i, t-1$ & & & .0002209 & $0.008^{* \star *}$ & & & -.0003363 & 0.158 \\
\hline$P B_{i, t-1}$ & -.1120721 & 0.263 & -.1143308 & 0.253 & .2292137 & $0.039^{* *}$ & .2285751 & $0.043^{* *}$ \\
\hline$S I Z E_{i, t-1}$ & -.7417243 & $0.000^{* * *}$ & -.753402 & $0.000^{* \star *}$ & -.0853912 & 0.740 & -.0927056 & 0.727 \\
\hline LEV $_{\mathrm{i}, \mathrm{t}-1}$ & -.7205327 & 0.563 & -.7889774 & 0.536 & -1.770368 & $0.003^{\star \star \star *}$ & -1.91525 & $0.001^{* * *}$ \\
\hline Cons & 18.94428 & $0.000^{* \star *}$ & 19.61791 & $0.000^{\star \star \star *}$ & 4.413879 & 0.441 & 4.026451 & 0.504 \\
\hline F-Statistic & 27.22 & & 25.71 & & 73.92 & & 220.66 & \\
\hline Nb. Obs & 333 & & 333 & & 151 & & 151 & \\
\hline
\end{tabular}

Notes: This table provides the results of Driscoll-Kray standard errors estimation using PB as the dependent variable. All data are reported in annual frequency for the period 2011 through $2017 .{ }^{* \star *}$, ${ }^{\star *}$, and ${ }^{*}$ specify significance at $1 \%, 5 \%$, and $10 \%$ levels, respectively. 
Appendix I Table 5. Results for ESG pillar vs ROA regression by industry

\begin{tabular}{|c|c|c|c|c|c|c|c|c|}
\hline & \multicolumn{4}{|c|}{ Capital Goods } & \multicolumn{4}{|c|}{ Transportation } \\
\hline & \multicolumn{2}{|c|}{ Model 3} & \multicolumn{2}{|c|}{ Model 4} & \multicolumn{2}{|c|}{ Model 3} & \multicolumn{2}{|c|}{ Model 4} \\
\hline & Coeff & P-value & Coeff & P-value & Coeff & P-value & Coeff & P-value \\
\hline ENV $_{\mathrm{i}, \mathrm{t}-1}$ & .0087844 & 0.206 & -.116744 & $0.001^{* * *}$ & -.010191 & 0.333 & -.0632324 & $0.012^{\star *}$ \\
\hline $\operatorname{SOC}_{i, t-1}$ & -.0251313 & $0.075^{*}$ & .02749 & $0.074^{*}$ & .0452302 & $0.000^{* * *}$ & .1501058 & $0.000^{* * * *}$ \\
\hline $\mathrm{GOV}_{\mathrm{i}, \mathrm{t}-1}$ & -.0017345 & 0.714 & -.020756 & 0.682 & -.0272531 & $0.007^{* * *}$ & .0658032 & $0.023^{\star *}$ \\
\hline $\mathrm{ENV}^{2} \mathrm{i}, \mathrm{t}-1$ & & & .001377 & $0.001^{* \star *}$ & & & .0004662 & $0.075^{*}$ \\
\hline $\operatorname{SOC}^{2} \mathrm{itt-1}$ & & & -.000587 & $0.021^{* *}$ & & & -.0010773 & $0.000^{* * *}$ \\
\hline $\mathrm{GOV}^{2} \mathrm{i,t-1}$ & & & .000204 & 0.693 & & & -.0009173 & $0.000^{* * *}$ \\
\hline $\mathrm{ROA}_{\mathrm{i}, \mathrm{t}-1}$ & .1180231 & $0.064^{*}$ & .114953 & $0.057^{*}$ & -.1015722 & $0.031^{* *}$ & -.0869621 & $0.055^{\star}$ \\
\hline$S I Z E_{i, t-1}$ & -1.706522 & $0.000^{* * *}$ & -1.72516 & $0.000^{* \star *}$ & -5.541707 & $0.000^{* * *}$ & -5.314858 & $0.000^{* * *}$ \\
\hline LEV $_{i, t-1}$ & -6.227386 & $0.034^{* *}$ & -6.27329 & $0.039^{* *}$ & 5.197448 & 0.123 & 3.208515 & 0.371 \\
\hline Cons & 44.19147 & $0.000^{* * *}$ & 46.2546 & $0.000^{* * *}$ & 125.8174 & $0.000^{* * *}$ & 118.7898 & $0.000^{* * *}$ \\
\hline F-Statistic & 156.93 & & 66.49 & & 193.36 & & 80.24 & \\
\hline Nb. Obs & 383 & & 383 & & 159 & & 159 & \\
\hline
\end{tabular}

Notes: This table provides the results of Driscoll-Kray standard errors estimation using ROA as the dependent variable. All data are reported in annual frequency for the period 2011 through $2017 .{ }^{* * *},{ }^{* *}$, and ${ }^{*}$ specify significance at $1 \%, 5 \%$, and $10 \%$ levels, respectively

Appendix I Table 6. Results for ESG pillar vs ROE regression by industry

\begin{tabular}{|c|c|c|c|c|c|c|c|c|}
\hline & \multicolumn{4}{|c|}{ Capital Goods } & \multicolumn{4}{|c|}{ Transportation } \\
\hline & \multicolumn{2}{|c|}{ Model 3} & \multicolumn{2}{|c|}{ Model 4} & \multicolumn{2}{|c|}{ Model 3} & \multicolumn{2}{|c|}{ Model 4} \\
\hline & Coeff & P-value & Coeff & P-value & Coeff & P-value & Coeff & P-value \\
\hline ENV $_{\mathrm{i}, \mathrm{t}-1}$ & .0132038 & 0.613 & -.311015 & $0.001^{* * *}$ & -.0394364 & 0.404 & -.2702075 & $0.078^{*}$ \\
\hline $\mathrm{SOC}_{\mathrm{i}, \mathrm{t}-1}$ & -.0702509 & 0.134 & .120919 & $0.012^{\star *}$ & .1333394 & $0.000^{* * *}$ & .4026058 & $0.000^{* * *}$ \\
\hline $\mathrm{GOV}_{\mathrm{i}, \mathrm{t}-1}$ & .0062757 & 0.754 & -.051949 & 0.738 & -.0246914 & 0.494 & .4484696 & $0.002^{* * *}$ \\
\hline $\mathrm{ENV}^{2} \mathrm{i}, \mathrm{t}-1$ & & & .003519 & $0.002^{\star * *}$ & & & .0021127 & 0.250 \\
\hline $\operatorname{SOC}^{2} \mathrm{i}, \mathrm{t}-1$ & & & -.002145 & $0.012^{\star *}$ & & & -.0026248 & $0.000^{* * *}$ \\
\hline $\mathrm{GOV}^{2} \mathrm{i}, \mathrm{t}-1$ & & & .000618 & 0.685 & & & -.004622 & $0.001^{* * *}$ \\
\hline $\mathrm{ROE}_{\mathrm{i}, \mathrm{t}-1}$ & .012852 & 0.891 & .006456 & 0.942 & -.0025604 & 0.981 & .0131327 & 0.903 \\
\hline SIZE $E_{i, t-1}$ & -4.819969 & $0.000^{* * *}$ & -4.77997 & $0.001^{* * *}$ & -15.17984 & $0.000^{* * *}$ & -14.27473 & $0.000^{* * *}$ \\
\hline $\operatorname{LEV}_{\mathrm{i}, \mathrm{t}-1}$ & -10.46368 & $0.060^{*}$ & -10.5183 & $0.078^{*}$ & 19.72033 & $0.003^{* * *}$ & 12.93007 & $0.065^{\star}$ \\
\hline Cons & 121.6491 & $0.000^{* * *}$ & 124.363 & $0.000^{* * *}$ & 334.7208 & $0.000^{* * *}$ & 306.6685 & $0.000^{* * *}$ \\
\hline F-Statistic & 14.21 & & 16.31 & & 128.83 & & 911.18 & \\
\hline $\mathrm{Nb}$. Obs & 383 & & 383 & & 159 & & 159 & \\
\hline
\end{tabular}

Notes: This table provides the results of Driscoll-Kray standard errors estimation using ROE as the dependent variable. All data are reported in annual frequency for the period 2011 through $2017 .{ }^{* \star *},{ }^{\star *}$, and ${ }^{*}$ specify significance at $1 \%, 5 \%$, and $10 \%$ levels, respectively. 
Appendix I Table 7. Results for ESG pillar vs RET regression by industry

\begin{tabular}{|c|c|c|c|c|c|c|c|c|}
\hline & \multicolumn{4}{|c|}{ Capital Goods } & \multicolumn{4}{|c|}{ Transportation } \\
\hline & \multicolumn{2}{|c|}{ Model 3} & \multicolumn{2}{|c|}{ Model 4} & \multicolumn{2}{|c|}{ Model 3} & \multicolumn{2}{|c|}{ Model 4} \\
\hline & Coeff & P-value & Coeff & P-value & Coeff & P-value & Coeff & P-value \\
\hline$E N V_{i, t-1}$ & .0607243 & 0.678 & .217685 & $0.098^{*}$ & -.071121 & $0.049^{* *}$ & -.7907963 & $0.023^{\star \star}$ \\
\hline $\mathrm{SOC}_{\mathrm{i}, \mathrm{t}-1}$ & .3496736 & $0.008^{* \star *}$ & .328602 & $0.001^{* * *}$ & .3417601 & $0.020^{\star *}$ & .4488736 & 0.258 \\
\hline $\mathrm{GOV}_{\mathrm{i}, \mathrm{t}-1}$ & -.1651165 & $0.000^{* * *}$ & -1.13297 & $0.000^{* * *}$ & -.3069003 & $0.052^{*}$ & .1689899 & 0.782 \\
\hline $\mathrm{ENV}^{2} \mathrm{i}, \mathrm{t}-1$ & & & -.001865 & 0.112 & & & .007396 & $0.029^{\star \star}$ \\
\hline $\mathrm{SOC}^{2} \mathrm{i}, \mathrm{t}-1$ & & & .000448 & 0.747 & & & -.0004712 & 0.930 \\
\hline $\mathrm{GOV}^{2} \mathrm{i}, \mathrm{t}-1$ & & & .010174 & $0.000^{* * *}$ & & & -.004163 & 0.376 \\
\hline $\mathrm{RET}_{\mathrm{i}, \mathrm{t}-1}$ & -.2047289 & $0.027^{\star \star}$ & -.208026 & $0.017^{\star \star}$ & -.1732583 & $0.000^{\star * \star}$ & -.1904739 & $0.000^{\star * \star}$ \\
\hline$S I Z E_{i, t-1}$ & -16.02214 & $0.000^{\star * \star}$ & -15.9356 & $0.000^{* * *}$ & -24.06874 & $0.004^{\star * \star}$ & -21.01985 & $0.003^{* * * *}$ \\
\hline LEV $_{\mathrm{i}, \mathrm{t}-1}$ & -31.06712 & 0.164 & -36.2368 & 0.130 & 80.46814 & $0.000^{* * *}$ & 76.82197 & $0.000^{\star * *}$ \\
\hline Cons & 397.7781 & $0.000^{* * * *}$ & 412.9988 & $0.000^{* * *}$ & 540.0082 & $0.003^{* * *}$ & 472.1794 & $0.001^{\star \star *}$ \\
\hline F-Statistic & 59.89 & & 33.86 & & 14.55 & & 6.47 & \\
\hline Nb. Obs & 332 & & 332 & & 136 & & 136 & \\
\hline
\end{tabular}

Notes: This table provides the results of fixed effects with robust and clustered standard errors using RET as the dependent variable. All data are reported in annual frequency for the period 2011 through $2017 .{ }^{* \star *},{ }^{* \star}$, and ${ }^{*}$ specify significance at $1 \%, 5 \%$, and $10 \%$ levels, respectively.

Appendix I Table 8. Results for ESG pillar vs PB regression by industry

\begin{tabular}{|c|c|c|c|c|c|c|c|c|}
\hline & \multicolumn{4}{|c|}{ Capital Goods } & \multicolumn{4}{|c|}{ Transportation } \\
\hline & \multicolumn{2}{|c|}{ Model 3} & \multicolumn{2}{|c|}{ Model 4} & \multicolumn{2}{|c|}{ Model 3} & \multicolumn{2}{|c|}{ Model 4} \\
\hline & Coeff & P-value & Coeff & P-value & Coeff & P-value & Coeff & P-value \\
\hline $\mathrm{ENV}_{\mathrm{i}, \mathrm{t}-1}$ & -.0049364 & 0.117 & -.0163815 & 0.201 & -.0048143 & 0.431 & -.007394 & 0.654 \\
\hline $\mathrm{SOC}_{\mathrm{i}, \mathrm{t}-1}$ & .0033859 & $0.093^{*}$ & -.0010855 & 0.859 & -.0057423 & 0.180 & -.013769 & 0.252 \\
\hline $\mathrm{GOV}_{\mathrm{i}, \mathrm{t}-1}$ & -.002448 & $0.000^{* * *}$ & -.0235244 & $0.000^{* * *}$ & -.002005 & 0.340 & .0059468 & 0.411 \\
\hline ENV $^{2} \mathrm{i}, \mathrm{t}-1$ & & & .0001257 & 0.270 & & & .000033 & 0.759 \\
\hline $\mathrm{SOC}^{2} \mathrm{i}, \mathrm{t}-1$ & & & .000058 & 0.343 & & & .0000903 & 0.395 \\
\hline $\mathrm{GOV}^{2} \mathrm{i}, \mathrm{t}-1$ & & & .0002277 & $0.001^{* * *}$ & & & -.000075 & 0.376 \\
\hline$P B_{i, t-1}$ & -.1132853 & 0.256 & -.1194684 & 0.218 & .2425834 & $0.045^{\star *}$ & .2321531 & $0.061^{*}$ \\
\hline$S I Z E_{i, t-1}$ & -.7187498 & $0.001^{* * *}$ & -.7407037 & $0.001^{* * *}$ & .0149763 & 0.943 & .0160484 & 0.947 \\
\hline LEV $_{\mathrm{i}, \mathrm{t}-1}$ & -.6661668 & 0.590 & -.8024381 & 0.525 & -2.098095 & $0.001^{* * *}$ & -1.97476 & $0.001^{* * *}$ \\
\hline Cons & 18.48052 & $0.000^{* * *}$ & 19.66285 & $0.000^{* * *}$ & 2.335208 & 0.610 & 2.261938 & 0.659 \\
\hline F-Statistic & 80.07 & & 15.08 & & 4.73 & & 8.16 & \\
\hline Nb. Obs & 333 & & 333 & & 151 & & 151 & \\
\hline
\end{tabular}

Notes: This table provides the results of Driscoll-Kray standard errors estimation using PB as the dependent variable. All data are reported in annual frequency for the period 2011 through 2017 . ${ }^{* *},{ }^{* *}$, and ${ }^{*}$ specify significance at $1 \%, 5 \%$, and $10 \%$ levels, respectively. 